\title{
SEDIMENTOLOGY
}

\section{Early Jurassic palaeoenvironments in the Surat Basin, Australia - marine incursion into eastern Gondwana}

\begin{tabular}{|r|l|}
\hline Journal: & Sedimentology \\
\hline Manuscript ID & SED-2019-OM-101.R1 \\
\hline Manuscript Type: & Original Manuscript \\
\hline Date Submitted by the \\
Author: & n/a \\
\hline Complete List of Authors: & $\begin{array}{l}\text { La Croix, Andrew; University of Queensland, Energy Initiative } \\
\text { He, Jianhua; Chengdu University of Technology, Key Laboratory of Oil } \\
\text { and Gas Reservoir Geology and Exploitation } \\
\text { Bianchi, Valeria; University of Queensland, School of Earth and } \\
\text { Environmental Sciences } \\
\text { Wang, Jiahao; China University of Geosciences, Faculty of Earth } \\
\text { Resource } \\
\text { Gonzalez, Sebastian; University of Queensland, Centre for Coal Seam } \\
\text { Gas } \\
\text { Underschultz, Jim; University of Queensland, Centre for Coal Seam Gas }\end{array}$ \\
\hline Keywords: & $\begin{array}{l}\text { Precipice Sandstone, Evergreen Formation, Surat Basin, Jurassic, } \\
\text { Gondwana, Pangea, palaeoenvironments, palaeogeography }\end{array}$ \\
\hline
\end{tabular}

\section{SCHOLARONE


Early Jurassic paleoenvironments in the Surat Basin, Australia - marine incursion into eastern Gondwana

Andrew D. La Croix ${ }^{1,2^{*}}$, Jianhua He ${ }^{1,3}$, Valeria Bianchi ${ }^{4}$, Jiahao Wang ${ }^{1,5}$, Sebastian Gonzalez ${ }^{6}$, and Jim R. Undershultz ${ }^{6}$

${ }^{1}$ Energy Initiative, University of Queensland, Brisbane 4072, Australia

${ }^{2}$ School of Science, University of Waikato, Hamilton 3240, New Zealand

${ }^{3}$ Key Laboratory of Oil and Gas Reservoir Geology and Exploitation, Chengdu University of Technology, Chengdu 610059, China

${ }^{4}$ School of Earth and Environmental Sciences, University of Queensland, Brisbane 4072, Australia

${ }^{5}$ Key Laboratory of Petroleum Resources, China University of Geosciences, Wuhan 430074, China

${ }^{6}$ Centre for Coal Seam Gas, University of Queensland, Brisbane 4072, Australia

Corresponding author: Andrew D. La Croix; andrew.lacroix@waikato.ac.nz

Keywords: Precipice Sandstone; Evergreen Formation; Surat Basin; Gondwana; Pangea; Jurassic; palaeoenvironments; palaeogeography. 


\section{Abstract}

Interpretations of paleodepositional environments and paleogeography are important for reconstructing Earth history. Only a small number of attempts have been made at mapping the Jurassic depositional environments of eastern Australia. Consequently, a detailed understanding of the setting of Australia in Gondwana is lacking. Core, wireline logs, 2D, and 3D seismic data from the Precipice Sandstone and Evergreen Formation in the Surat Basin have been used to construct maps that show the evolution of depositional environments through the Early Jurassic.

The results show that the succession consists of three $3^{\text {rd }}$ order sequences (SQ1-SQ3) that were controlled by eustatic changes in sea level. The lowstand systems tract in SQ1 comprises braided river and braid delta deposits, confined to a narrow strip that parallels the basin centre. The strata initially were deposited in two sub-basins atop an unconformity surface, with rivers flowing in different orientations depending upon the sub-basin. The transgressive systems tract of SQ1 to lowstand systems tract of SQ3 is dominated by fluvial-deltaic systems that built towards a single merged basin centre. Finally, the transgressive and highstand systems tracts of SQ3 show nearshore deposits building towards a shallow marine basin centre. In the youngest part of this interval, ironstone shoals are the most conspicuous facies, the thickness and number of which increase with increasing marine-influence. We interpret a corridor to the open ocean through the Clarence-Moreton Basin or to the Carpentaria and Papuan basins, evidence of which has since been eroded.

Our results challenge a commonly held view that eastern Australian basins were not influenced by eustasy. We propose a much more dynamic paleogeographic setting comprising a complex mixture of fluvial, deltaic, and shallow marine sedimentary environments. This work can be used in the future to unravel the stratigraphic relationships between Mesozoic eastern Australian basins, or by geoscientists working in other basins globally as an analogue for understanding the complex interplay of paralic depositional systems in data poor areas. 


\section{Introduction}

Reconstruction of paleodepositional environments and paleogeography are highly sought after because of their implications for understanding the organization of continents (Scotese and McKerrow, 1990; Zhang et al., 2004; Ingersoll, 2012; Cawood et al., 2018), past climatic conditions (Kutzbach and Gallimore, 1989; Postma, 2001; Wang et al., 2013; Zeng et al., 2019), faunal distribution patterns (Fastovsky, 1987; Viseras et al., 2006), and for improving exploration and modelling of water, energy, and mineral resources (La Croix et al., 2013; Deveugle et al., 2014; Howell et al., 2014; Lech et al., 2016; Nyberg and Howell, 2016; La Croix et al., 2017; La Croix et al., 2019b). The interpretation of depositional environments commonly relies upon outcrop and core observations (Burbank and Verges, 1994; Baniak et al., 2014; Ainsworth et al., 2015; Jones et al., 2018), as well as analogues to modern settings (Gingras et al., 1999; La Croix et al., 2019a). Additional data that have been used to bolster mapping and interpretation includes macro- and micro-fossils (Ellison, 1951; Carboni et al., 2010; Pilarczyk et al., 2014), sediment geochemistry (Eganhouse and Kaplan, 1988; Jiang and George, 2018), as well as seismic and other sub-surface imaging techniques (Wooldridge and Hickin, 2005; Zhu et al., 2017). Geochronology has also been applied to constrain the timing and evolution of depositional systems (Bauch et al., 1999; Shu et al., 2006; DeCelles et al., 2007; McDougall, 2008). However, real world datasets used to map the distribution of depositional environments through time are often sparse, incomplete, and spread over large distances. It is commonly impractical or even impossible to get an accurate depiction of past landscapes at regional scales. To mitigate this problem, a substantial body of recent research has focused on using petrophysical wireline logs to interpret sedimentary facies and their associated depositional environments (e.g., Wang and Timothy, 2013; He et al., 2016; He et al., 2019). This is due to the abundance of wireline logs collected from petroleum-bearing sedimentary basins, the relatively high vertical resolution of logs, as well as the fact that logs commonly intersect large sections of the stratigraphic column.

Only a few regional accounts of the depositional environments in eastern Australia during the Jurassic currently exist in the public domain (Fig. 1; Frakes et al., 1987; Bradshaw and Yeung, 1990; Struckmeyer and Totterdell, 1990; Bradshaw and Yeung, 
1992; Bianchi et al., 2018; Wainman and McCabe, 2018). However, the resolution of the maps derived from these studies are relatively low and the datasets are limited in their stratigraphic and/or geographic scope. Australia is one of the major continental fragments that comprised Gondwana - the southern portion of Pangea. It was situated along the eastern Gondwana margin both adjacent to the Tethys Ocean and facing the Panthalassa Ocean (Veevers, 2000). The stratigraphic succession contained in the Great Australian Superbasin (Eromanga, Surat, Carpentaria, Clarence-Moreton, Nambour, Laura, Peninsula, and Money Shoals basins; Jell, 2013) is relatively complete and records important information about the nature of Gondwana prior to and during initial breakup of Pangea around 185 Ma (Veevers, 2004; 2006). Updated conceptualizations are needed that utilize multidisciplinary techniques and datasets to improve our understanding of depositional environments in the Jurassic of eastern Australia. This is especially true in the context of global sea level changes and tectonics.

To fill the gap in understanding of the paleo-depositional environments in eastern Australia, in this study we integrate data from core, wireline logs, as well as $2 D$ and $3 D$ seismic from the Precipice Sandstone and Evergreen Formation in the Surat Basin. The main objectives of this work were to provide a series of "time-slice" maps, showing the evolution of environments and associated geobody distributions. With these facies and environment maps, the paleogeographic context of Jurassic eastern Australia can be refined and linked with eustatic sea level cycles (e.g., Haq et al., 1987). This will significantly contribute to understanding the relationship between eastern Gondwana and other related terranes such as Zealandia.

\section{Geological Setting}

\subsection{Global Context of the Australian Continent}

From the Neoproterozoic to the Mesozoic ( 650-100 Ma), Australia was positioned next to Antarctica and India, with Africa and South America situated further west, together forming Gondwana as the southern landmass of Pangea (Veevers, 2004). In the earliest Jurassic ( $201 \mathrm{Ma}$ ), initial rifting between Antarctica and Australia had occurred, though Gondwana had not yet begun to break up (Quilty, 1984; Bomfleur 
et al., 2014). A tensional tectonic regime characterized much of the Australian continent with the northwestern margin becoming increasingly faulted, producing abundant rift valleys as the greater Indian landmass was wrenched away (Veevers et al., 1984). In contrast, convergent tectonics were occurring in the northeastern quadrant, with a subduction zone located offshore of the Maryborough Basin (Veevers, 1984; Bradshaw and Yeung, 1992). Finally, at approximately $185 \mathrm{Ma}$ Gondwana began to break up, subsequently forming the more familiar dispersed arrangement of continents that characterizes the globe today (Veevers, 2004).

Through the development, evolution, and breakup of Gondwana the Australian continent shifted significantly in paleo-latitude and orientation. Apparent polar wander paths show that Australia was at high latitudes through most of the Mesozoic, commonly above $60^{\circ} \mathrm{S}$, until it migrated northward during separation from Antarctica (Schmidt and Clark, 2000; Fig. 2). The change in paleolatitude produced a strong monsoonal climate, and correspondingly affected the distribution of flora and fauna in eastern Australia (McKellar, 1998; 2004; Turner et al., 2009; de Jersey and McKellar, 2013). Around the beginning of the Jurassic a change also occurred in Pangea's direction of rotation - from anticlockwise to clockwise. During the Jurassic and Cretaceous a sizeable portion of eastern Australia was occupied by the Great Australian Superbasin recording sedimentation as a response to tectonics and global eustasy (Veevers, 1984).

\subsection{Structure and Basin Formation}

The Surat Basin is in the eastern portion of the extensive Great Australian Superbasin, enveloping an area of $327,000 \mathrm{~km}^{2}$ in Queensland and New South Wales, Australia (Fig. 3). The Surat is time equivalent to the Eromanga and Clarence-Moreton basins and depositional continuity occurred across the Nebine and Kumbarilla ridges to the west and east, respectively (Power and Devine, 1970; Exon and Senior, 1976; Green et al., 1997). The Surat Basin is a shallow platform depression that sits unconformably atop the Bowen and Gunnedah basins, and partly rests upon Palaeozoic, and Permo-Triassic rocks. The basin axis is defined by the north-south trending Mimosa Syncline, roughly corresponding to the Taroom Trough which is the 
thickest part of the Bowen Basin (Exon, 1976; Fielding et al., 1990).

The tectonic mechanisms that produced the Surat Basin are not widely agree upon, with three main models being proposed: 1) thermal subsidence (Korsch et al., 1989; Fielding et al., 1990); 2) dynamic platform tilting (Gallagher et al., 1994; Korsch and Totterdell, 2009; Waschbusch et al., 2009); and, 3) intraplate rifting (Fielding, 1996). The tectonic history remains poorly constrained and both intracratonic (Fielding, 1996; Yago and Fielding, 1996) and pericratonic basin types have been suggested (Veevers et al., 1982; Gallagher, 1990). The basin is relatively undeformed though a few important structural features occur (Fig. 3). Of these, the most prominent basement structures are the Auburn Arch in the northwest, the Yarraman Block in the northeast, and the Texas Block in the southeast. These fault blocks were major sediment sources, but became less exposed as time progressed and the basin was filled (Green et al., 1997). The sedimentary succession is no longer at its maximum burial depths because a substantial thickness of sediment has been eroded from the Surat Basin due to midCretaceous uplift - up to 2500 m in the eastern part (Gallagher et al., 1994; Raza et al., 2009).

\subsection{Sedimentation Cycles and Stratigraphy}

According to Exon and Burger (1981), the sedimentary fill of the Surat Basin was delivered in six major pulses, culminating in a stratigraphic thickness of over $2500 \mathrm{~m}$. The cycles lasted between 10-20 Ma, corresponding to $2^{\text {nd }}$ order global tectonic and sedimentation cycles (cf. Wilson, 1968; Burke, 2011). Three cycles occurred in the Jurassic, one spanned the Jurassic-Cretaceous boundary, and two took place in the Cretaceous. The cycles are informally known as: (1) the Precipice-Evergreen, (2) the Hutton-Walloon, (3) the Springbok-Westbourne, (4) the Gubbermunda-Orallo, (5) the Mooga-Bungil, and (6) the Wallumbilla cycles. We focus on the first cycle - the Precipice-Evergreen cycle.

Stratigraphic correlation across the Surat Basin has garnered substantial effort over several decades (Gray, 1968; Power and Devine, 1970; Mollan et al., 1972; Exon, 1976; Green et al., 1997; Hoffmann et al., 2009; Totterdell et al., 2009; Waiman et al., 2018; Wang et al., 2019). Yet despite the relatively flat lying nature of the strata, a set of 
lithostratigraphic terminology that is agreed upon for every interval beyond the local area has not been established. The most basic lithostratigraphic scheme proposed by McKellar (1998) is preferred herein (Fig. 4). More recently, workers have focused on packaging rocks according to their age and genetic relationships using a sequence stratigraphic framework (Wells et al., 1994; Hoffmann et al., 2009; Totterdell et al., 2009; Ziolkowski et al., 2014; Wang et al., 2019). The most recent stratigraphic scheme of Wang et al. (2019) illustrates a Precipice Sandstone and Evergreen Formation that consist of three $3^{\text {rd }}$-order sequences corresponding to global sea level fluctuations occurring during the Jurassic (Fig.4; Haq et al., 1987).

\subsection{Sedimentary Environments}

The Precipice Sandstone is generally regarded to represent braided river deposits that accumulated in an upland area, and therefore not under the control of sea level (Sell et al., 1972; Exon, 1976; Exon and Burger, 1981; Martin, 1981; Green et al., 1997). However, an updated view is emerging based on sedimentological, ichnological, palynological, and microfossil evidence that the Precipice Sandstone was more likely deposited in a nearshore and shallow marine setting (Bianchi et al., 2018; Martin et al., 2018; La Croix et al., 2019b). In this context, eustatic sea level was very important in the distribution of depositional environments and the resulting architecture of strata (Wang et al., 2019).

Interpretations of the Evergreen Formation generally agree that it was deposited by meandering rivers flowing into standing bodies of water, and that a regional transgression occurred as deposition ensued (Dickins and Malone, 1973; Exon, 1976; Cosgrove and Mogg, 1985; Fielding et al., 1990; Cranfield et al., 1994). However, the cause of the regional transgression is not agreed upon. One hypothesis is that the Westgrove Ironstone Member represents lacustrine / freshwater deposits (e.g., Cranfield et al., 1994; Green et al., 1997), and another links the interval with marine incursions (e.g., Mollan et al., 1969; Mollan et al., 1972; Bradshaw and Challinor, 1992; La Croix et al., 2019b), and thus it is postulated that sea level had a major influence on deposition. 


\section{Dataset and Methods}

Core, wireline logs (including Formation Micro-images [FMI]), 2D, and 3D seismic were utilized as part of this study. The core dataset consisted of ten drill holes that intersected a substantial thickness of the Precipice Sandstone and Evergreen Formation. These are: Chinchilla 4, Condabri MB9-H, Kenya East GW7, Moonie 31, Moonie 34, Reedy Creek MB3-H, Roma 8, Taroom 17, West Wandoan 1, and Woleebee Creek GW4. For the most part, core was recovered from the northern portion of the Surat Basin, although Kenya East GW7 and Moonie 31 and 34 are situated on the eastern flank (Fig. 3).

Facies analysis was undertaken on the core, consisting of detailed descriptions of lithology, physical sedimentology, and ichnology. A subset of 61 samples was collected from muddy facies and these samples were analyzed for their palynological content (cf. La Croix et al., 2019b). From the core, sets of facies (CF) were defined, each representing a distinctive depositional sub-environment.

One hundred and eighty-eight drill holes had sufficient suites of wireline logs and were used for wireline log facies interpretation (Fig. 5). The minimum set of logs needed for analysis was gamma ray, density, neutron, and sonic logs. Photoelectric factor and resistivity logs were secondary but improved the prediction accuracy of facies. Linear discriminate analysis was used to simplify the CF into a simple set of wireline log facies (WLF) that could be recognized in the absence of core. Using the core dataset an artificial neural network was trained to predict WLFs for all 188 drill holes (cf. He et al., 2019). A series of facies maps was produced using the WLF predictions from across the basin. The WLF with the greatest cumulative thickness in each stratigraphic interval was used as point data, and this distribution was mapped using the shale content of drill holes calculated from gamma ray logs (i.e., $\mathrm{V}_{\text {shale }}$ ) as a guide.

Palaeocurrent measurements were derived from CMI logs in selected drill holes (Condabri MB9-H, West Wandoan 1, and Woleebee Creek GW4). These were merged with palaeocurrent data from the outcrop belt along the northern margin of the basin based on Bianchi et al. (2018) and Martin (1981). Palaeocurrent interpretations from logs were corrected by removing regional structural dip inferred from the shale bedding. Dip directions were filtered by removing data with dips less than $8^{\circ}$, to disregard any 
planar bedding. Outcrop measurements were collected from planar tabular and trough cross-bedded sandstones. The combined dataset was used as broad scale palaeoflow indicators to support facies mapping interpretations.

Five hundred and twenty drill holes with gamma ray logs were used for stratigraphic correlation across the basin. The main sequence stratigraphic surfaces were interpreted in core and then transposed to drill holes using their wireline log motif. A network of cross sections facilitated stratigraphic correlation across the basin (cf. Wang et al., 2019). A total of $9250 \mathrm{~km}$ of 2D seismic data, and three 3D volumes were used to support the stratigraphic interpretation. Core was tied to logs, and then synthetic seismograms were used to tie logs to seismic and to recognize the main reflectors with regional significance. Shot point data was used to convert seismic surfaces to depth, especially in regions where well data was sparse. Based on the sequence stratigraphy, a series of structure and isopach thickness maps were produced for each major interval.

\section{Results}

\subsection{Sequence Stratigraphy}

The Precipice Sandstone and Evergreen Formation consist of three $3^{\text {rd }}$-order depositional sequences, SQ1-SQ3, from base to top (Wang et al., 2019). Each sequence is defined by a basal unconformity (J10, SB2, J20, J30), contains a transgressive surface (TS1, TS3) and a maximum flooding surface (MFS1, MFS3), and is marked by an unconformity at the top. These segment the sequences into a lowstand systems tract, transgressive systems tract, and highstand systems tract, respectively (Figs. 4 and 6). However, a transgressive surface was only picked from the basal and top sequences (SQ1 and SQ3); the second sequence of the three (SQ2) was relatively thin and the associated internal stratigraphic subdivisions were difficult to trace across most of the basin, possibly due to merging of stratigraphic surfaces. Therefore, TS2 and MFS2 surfaces were not correlated.

In core, the lowstand systems tracts consist of sedimentary facies (usually channel sandstones) with aggradational stacking patterns. The transgressive systems tracts show back stepping facies relationships that are represented by distal over proximal relationships. The highstand systems tracts are represented by progradational 
facies stacking patterns with proximal over distal relationships. Facies stacking patterns were also inferred using the gamma ray log. Aggradation is represented by generally thick, low gamma ray (clean sandstone) motifs. Retrogradation is interpreted from an abundance of low gamma ray to high gamma ray up section (i.e., fining-upward) packages that are generally 3-5 m thick. Finally, progradational facies stacking was inferred from overall high gamma ray to low gamma ray up section (i.e., coarseningupward) packages that range in thickness from 3-5 m. The stratigraphy is composed of the surfaces: J10 (base-Precipice unconformity), TS1, MFS1, SB2, J20, TS3, MFS3, and $\mathrm{J} 30$, from base to top.

Five seismic events were identified from well ties and synthetic seismograms, of which three were able to be traced across large sections of the basin: Seismic Event 5, Seismic Event 4, and Seismic Event 2, from bottom to top (Fig. 7). Seismic Event 1 and 3 were localized reflectors that did not always correspond to regionally important stratigraphic surfaces. The seismic reflectors were approximations of surfaces observed in core. Seismic Event 5, coincides with the $\mathrm{J} 10$ / base-Precipice unconformity and defined the base of SQ1. Seismic Event 4 correlates with the TS1 surface, demarcating the top of the lowstand systems tract in SQ1. Finally, Seismic Event 2 occurs near the TS3 surface and corresponds to the base of the transgressive systems tract of SQ3.

At basin-scale, SQ2 is very thin (from approximately $5-15 \mathrm{~m}$ thick), as is the lowstand systems tract of SQ3 (i.e., between J20 and TS3; from approximately 20-55 m thick). These stratigraphic intervals were combined together for mapping. Thus, facies maps were produced for the intervals from J10-TS1, TS1-MFS1, MFS1-SB2, SB2TS3, and TS3-J30. They represent the LST of SQ1, the TST of SQ1, the HST of SQ1, an interval that approximates SQ2, and the combination of the TST and HST of SQ3, respectively (Fig. 4).

\subsection{Structure and Thickness}

Structural elevation maps for the main sequence stratigraphic surfaces are displayed in Figure 8. They show that the J10 surface varies between -2365-721 meters above sea level (masl), with the deepest parts occurring along the axis of the 
Mimosa Syncline and progressively shallowing towards the southern, eastern, and western basin margins, as well as towards the outcrop belt in the north (Fig. 8A). The TS1 surface ranges in depth from -2261-800 masl. The structure broadly parallels the $\mathrm{J} 10$ surface and it becomes co-planar with $\mathrm{J} 10$ on the western side of the basin onto the Roma Shelf and Wunger Ridge (Fig. 8B). MFS1 varies from -2241-850 masl. The surface parallels J10 and TS1, but becomes co-planar with J10/TS1 on the Roma Shelf and Wunger Ridge, but further west than TS1 (Fig. 8C). SB2 ranges in depth from 2225-871 masl. It roughly parallels J10, TS1, and MFS1, and becomes co-planar with J10/TS1/MFS1 on the Roma Shelf and Wunger Ridge further east again from MFS1 (Fig. 8D). The TS3 surface varies from -2131-940 masl, and parallels underlying surfaces approximately, with the deepest parts occurring along the axis of the Mimosa Syncline (Fig. 8E). Finally, J30, ranges in depth from -2064-983 masl, and parallels the underlying surfaces similar to TS3 (Fig. 8F).

Isopach thickness maps for the main stratigraphic intervals are shown in Figure 9. The interval from J10-TS1 ranges in thickness from $0 \mathrm{~m}$ (where J10 and TS1 merge) to $151 \mathrm{~m}$ along the basin centre. The unit thins to the south, west, and east, but continues along the Mimosa Syncline with similar thickness to the basin-centre (Fig. 9A). Two main areas show the thickest accumulations; one in the southern-central portion and the other in the north-central portion, indicating a basement high (or decreased sediment accumulation) in the middle of the basin that trends approximately east to west. We refer to these two areas as the southern sub-basin (SSB) and northern sub-basin (NSB), respectively. The interval from TS1-MFS1 varies from 0-62 m thick. Slightly thicker sections occur at the basin centre and towards the east, the unit thins towards the southern and western flanks of the basin, and shows thickness continuity towards the outcrop belt in the north (Fig. 9B). From MFS1-SB2 the range in thickness is from 0-62 m. The thickest sections are within the central and eastern side of the basin and thickness is relatively continuous northward near the outcrop belt (Fig. 9C). The interval from SB2-TS3 varies from 4-152 m thick. No clear thickness trends are observed (Fig.9D). Finally, between TS3-J30 the thickness ranges from 26-119 m. The thickness is relatively even across the basin (Fig. 9E). 


\subsection{Facies Analysis}

Core analysis identified 15 CFs with unique sedimentological and ichnological characteristics (Table 1; Fig. 10). These are shown in Woleebee Creek GW4, our type well for the Precipice Sandstone and Evergreen Formation (Fig.11). The CFs combine into six facies associations representing braidplain, delta plain, subaqueous delta, deltainfluenced shoreface, tidally influenced shoreline, and restricted marine shoal depositional systems (He et al., 2019; La Croix et al., 2019). The braidplain association primarily consists of coarse-grained cross bedded sandstones, with subordinate gravel lags and mud-clast breccia representing migrating bedforms in high gradient depositional systems (Fig. 10A). The delta plain association is typified by a complex mixture of sandstone, mudstone, and coal facies. Sandstone facies represent distributary channels, channel levees, and crevasse splays (Fig. 10B). The mudstones, on the other hand, represent $t$ floodplains and interdistributary bays (Fig. 10D). Coal deposits are indicative of peat mires (Fig. 10C). The subaqueous delta association is characterized by sandstone, heterolithic sandstone and mudstone, as well as mudstone facies representing mouthbars (Fig. 10E), the delta front (Fig. 10F), and prodelta (Fig. 10G). The delta-influenced shoreface association comprises muddy sandstones and sandy mudstones with tempestites representing the lower shoreface (Fig. $10 \mathrm{H})$ and upper offshore, respectively. The tidally influenced shoreline association comprises heterolithic sandstone and mudstone deposits with abundant tidal structures. Finally, the restricted marine shoal association displays oolitic (Fig. 10I) and cemented ironstone deposits.

The 15 CFs were simplified into 10 WLFs (Table 1; Fig. 6). Not all CFs had corresponding WLFs due to a lack of distinctive petrophysical properties. Therefore, they could not be distinguished in logs. These were CF1 and CF2. In other cases, CFs were grouped together into a single WLF because of their similar log response characteristics. These facies could only readily be differentiated in core based on sedimentological and ichnological differences. The 10 WLFs consisted of the sandstone facies SA, SB, SC, and SD; the mudstone facies MA and MB; the heterolithic facies SMA and SMB, and the organic / miscellaneous facies OA and OB. These represent braided channel (SA), distributary channel (SB), crevasse splay or mouthbar (SC), and 
shoreface (SD) sandstones. MA is the WLF manifestation of floodplain mudstone, whereas MB represents interdistributary bay and upper offshore depositional environments. Delta front facies are represented by SMA and both the prodelta and tidal flats are represented by SMB. Finally, OA is the WLF equivalent of coal and OB is ironstone. Table 1 compares CFs and WLFs to demonstrate their equivalents. To differentiate WLFs with more than one corresponding CF (i.e., SC, MA, and SMB), the shape of the log motif was considered in context with the sequence stratigraphy, as well as the facies that sit above and below to make the most sensible interpretation.

\subsection{Palaeocurrents}

Palaeocurrent measurements derived from Martin (1980) and Bianchi et al. (2018) show a dominance of southeast and east directions along the western and central portion of the outcrop belt (NSB) in the stratigraphic interval from SB1-TS1 (Fig. 12B). Along the eastern side of the outcrop belt, palaeocurrents are directed towards the south and south-southeast. By and large, the spread of palaeocurrent directions are confined to a narrow range of up to $45^{\circ}$. Palaeocurrent data from the middle of the basin, corresponding to the southern portion of NSB and the northern portion of SSB, show directions that are dominantly to the east and south (Fig. 12B).

In the TS1-MFS1 interval palaeoflow indicators shift towards the north in NSB (Fig. 13B). On the western side of the outcrop belt they point due north within a narrow range. Along the central and eastern side of the basin palaeocurrents point northnorthwest to north-northeast with a wider range, up to approximately $90^{\circ}$. Palaeocurrents in the southern part of NSB and SSB, far from the outcrop belt, have palaeocurrents that are directed to the northeast, north, and to a lesser extent southwest (Fig. 13B).

Only a few palaeocurrent data points exist from the MFS1-SB2 interval, and they are from image logs in the basin-centre (Fig. 14B). The palaeocurrents show a dominance of west-flowing and south-flowing systems but with a wide dispersal.

Similarly, palaeocurrents were only documented in two locations from the SB2TS3 interval (Fig. 15B). In the north they are dominantly directed to the west and 
northwest, whereas in the south they show a weak NNW-SSE trend with a very large spread.

Finally, in the interval from TS3-J30, data from the northern portion of the basin show palaeocurrents spread widely in their direction with no clear trend. Data from further south is also spread widely, with dominant directions being north, northeast, southwest, and southeast (Fig. 16B).

\subsection{Distribution of WLFs and Paleo-Depositional Interpretation}

\subsubsection{J10-TS1}

During the LST of SQ1 (J10-TS1), the distribution of WLFs is rather monotonous; it is dominated by SA, with only two occurrences of SMA in the northeast and east (Fig. 12). Thus, the vast majority of the Surat Basin during J10-TS1 time consisted of braided rivers and braid deltas flowing into shallow water bodies (Bianchi et al., 2018; La Croix et al., 2019). The orientation of palaeo-currents suggest that these fluvial and fluvio-deltaic systems were fed from a source in the northwest and flowed towards the east in NSB (Fig. 12B; Martin, 1981; Bianchi et al., 2018). It remains uncertain what the source area was for SSB, but palaeoflow directions near the divide between the two sub-basins indicate that the SSB system flowed towards the east (Fig. 9A).

\subsubsection{TS1-MFS1}

In the TST of SQ1 (TS1-MFS1), SB is the dominant WLF in the northwestern and southeastern part of basin, whereas MA, SMA, and SMB are the prominent facies in the central portion. The edges of the basin were occupied by lower delta plain environments, with rivers interpreted to have been flowing north towards the presentday outcrop belt (i.e., northern portion of NSB), and towards the basin-centre forming the delta front and prodeltas of these systems in the southern NSB and SSB (Fig. 13A, $B)$. Younger deposits cut through older strata with complex cross-cutting relationships interpreted to have been derived from allogenic shifts in environments. These largescale deltas extended several tens of kilometers into the basin from the northwest. However, on the eastern margin of the basin, delta lobes do not show clear geometries 
in seismic data, and thus are not interpreted to have extended very far from their provenance areas (i.e., from the Auburn Arch and Yarraman Block). From the south, delta systems had much greater axial extents than on the southeastern and southwestern sides of the basin. Palaeocurrent data from the northern portion of the basin, within the outcrop belt, suggest that fluvio-deltaic systems were generally flowing from south to north and into shallow marine water bodies (Fig. 13B). Minor shoreface environments were distributed in the northeastern part of basin and tidal settings were distributed in the south.

\subsubsection{MFS1-SB2}

In the HST of SQ1 (TS1-SB2), Facies SB is the dominant WLF and SC is subordinate along the western, eastern, and southern portion of the study area (Fig. 14). A wider fairway (than the underlying interval TS1-MFS1) along the basin centre mostly comprises SMB, with a subordinate proportion of drill holes consisting of SMA and MA. From this distribution, we interpret that the main sedimentary environment was lower delta plain along the margins, transitioning into delta front and prodelta deposits towards the basin-centre and the outcrop belt in the north (Fig. 14B). Only the northwestern, eastern, and southeastern part of basin contained isolated delta systems, whereas in the rest of the basin delta systems were connected by long coastlines fed by many rivers. This was coupled with enhanced marine influence and an overall increase in water depths based on coastal and marine palynomorphs and marine trace fossils (La Croix et al., 2019b). West Wandoan 1 and Woleebee Creek GW4 are interpreted to be located near the locus of deposition, representing the "basin centre"; the two subbasins were merged at this stratigraphic level.

\subsubsection{SB2-TS3}

The distribution of WLFs in the SB2-TS3 interval predominantly consists of SB and SC along the western, eastern, and southern portions of the study area (Fig. 15). In contrast, along the axis of the Mimosa Syncline at the basin-centre, drill holes mostly comprise SMA, SMB, and MA. Thus, the interval was characterized by lower delta plain environments with abundant distributary channels rimming the study area. Large fluvio- 
deltaic systems flowing from the northwest and southeast prograded towards the central basin. We interpret that the sediment input from the southeast had increased relatively to older stratigraphic intervals based on palaeocurrent data (Fig. 15B). However, fluviodeltaic systems with an eastern provenance had much narrower delta plains compared to systems located on the western margins of the basin.

\subsubsection{TS3- SB4}

Near the top of the Evergreen Formation (TS3-SB4), the main WLFs are SB and SC along the western, southern, and eastern margins of the study area (Fig. 16). A wide fairway that extends from south to north into the outcrop belt dominantly comprises SMB with subordinate SMA. We interpret this to indicate that the entire basin was increasingly flooded by marine water, especially in the central and the northeastern parts of basin. Sediment was mainly derived from a western and southeastern provenance. Through time, the north and northeastern part of the basin were flooded which became the dominant areas that formed ooid shoals (Fig. 17). The maps of (oolitic) ironstone shows that both the number (Fig. 17A) and cumulative thickness (Fig. $17 \mathrm{~B}$ ) of these ironstone layers is greatest along the basin centre, as well as to the north and east near the outcrop belt. Shoreface mainly developed in the northeast, facing the open sea, whereas tidal environments were mainly restricted to a narrow fairway in the south.

\section{Discussion}

Given the current relatively simplistic understanding of palaeogeography in eastern Australia, our maps are useful for showing the evolution of depositional environments and placing Early Jurassic strata from the Surat Basin into a regional context. The distribution and orientation of wireline log facies allow us to make improved interpretations about sediment source areas, depositional sub-basins, fluctuations in relative sea level that controlled deposition, and to make inferences about the tectonic setting of the sedimentary basin. However, first, a summary of the depositional evolution is necessary. 


\subsection{Summary of the Evolution of Paleodepositional Environments}

The Early Jurassic land surface consisted of elevated basement blocks in the northwest (Auburn Arch), northeast (Yarraman Block), and southeast (Texas Block)(Fig. 3). These exposed basement blocks provided the main clastic input into the Surat Basin at the time. The Auburn Arch was composed of siliceous sedimentary and volcanic rocks; the Yarraman Block consisted of granite and gneiss; and the Texas Block was mainly composed of indurated fine-grained sediments (Green et al., 1997).

Deposition of the Precipice Sandstone commenced with a large fluvial and fluviodeltaic network developed along a corrugated and irregular topography incised into the Palaeozoic-Triassic Tasmanides Fold Belt. Braided rivers and braid deltas of the Precipice Sandstone progressively filled topographic lows along the unconformity surface with coarse grained sandstones and minor siltstone and mudstone deposits (J10-TS1; Fig. 12A). However, the Precipice Sandstone was restricted in lateral extent and onlapped the ridges that defined the basin to the west, south, and east (Fig. 9A; Wang et al., 2019). Furthermore, there appears to have been a remnant high that separated a depositional sub-basin in the south (SSB) from a northern sub-basin (NSB).

The dramatic shift in distribution of sedimentary environments above the Precipice Sandstone (i.e., TS1 surface and above), coincident with a eustatic rise in sea level (Haq et al., 1987) were taken as evidence of relative sea level control on deposition by Wang et al., (2019). The base of the Evergreen Formation was characterized by a shift from braided systems to lower energy fluvio-deltaic deposition (TS1-MFS1; Figs. 6, 11, 12A, 13A). Deposition expanded across the basin as the underlying topography was filled with sediment and the two depositional sub-basins merged into one. Topographic highs on the western basin margin (Wunger Ridge and Roma Shelf), in the south of the basin, and on the eastern flanks (Moonie-Goondiwindi Fault Systems) were a source of sediment that was shed towards the basin centre along the axis of the Mimosa Syncline or towards the north via distributary channels feeding delta lobes (c.f. Bianchi et al., 2018). Intervening areas between active delta lobes were characterized by interdistributary bays, tidal flats, and shorefaces. Ichnological and palynological data suggest that the basin centre was brackish to marine (Martin et al., 2018; La Croix et al., 2019b). Although there may have been 
small-scale rises and falls in relative sea level, overall transgression continued up section (i.e., MFS1-SB2 and SB2-TS3; Figs. 14 and 15).

Maximum relative sea level was achieved by the TS3-SB4 interval (Fig. 16), illustrated by the presence of oolitic ironstones with a widespread distribution (Fig. 17). By this point in time, most of the underlying Tasmanides structure was buried beneath a thick pile of sediment. In Europe, ironstones record high sea level conditions (Hallam, 1975), and in the Surat Basin it has been suggested that they relate to the Toarcian Anoxic Event (Ziolkowski et al., 2014). Debate remains over the lacustrine to shallow marine origin of the oolites (Mollan et al., 1972; Bradshaw and Challinor, 1992; Cranfield et al., 1994; Green et al., 1997), but intervening strata with marine trace fossils such as Asterosoma, Rhizocorallim, Scolicia, and Teichichnus suggests that at least periodically the water was both oxygenated and marine to brackish (La Croix et al., $2019 b)$. Additional evidence in support of the brackish water conditions is derived from the presence of acritarchs, dinocysts (Evans, 1962; Reiser and Williams, 1969; La Croix et al., 2019b), and shells of marginal to shallow marine affinity (Mollan et al., 1972). Ironstone deposition was widespread, extending to the Nambour and Clarence-Moreton basins (Bradshaw and Yeung, 1990). Finally, erosion of the top of the Evergreen Formation (i.e., J30 surface) separated muddy fluvial-deltaic sediment from the primarily thick and sandy deposits of the Hutton Sandstone.

\subsection{Sediment Source Areas and Depositional Sub-Basins}

Isopach thickness maps of the J10-TS1 interval show that there is a region in the north with thicknesses that exceed $120 \mathrm{~m}$, separated by a region with thicknesses of around $50 \mathrm{~m}$, from an area to the south with thicknesses of around $100 \mathrm{~m}$. This suggest that early deposition of the Precipice Sandstone may have been compartmentalized into two sub-basins; one sub-basin in the north centered around Woleebee Creek GW4 (NSB; Fig. 9A), with the other located in the south to the west of the Moonie Oil Field (SSB; Fig. 9A) separated by a structural high in between. The isopach thickness becomes more evenly distributed up-section, from the TS1-MFS1 through to the TS3J30 intervals. This supports the interpretation that the basin was progressively filled, and that the depositional sub-basins eventually (post TS1 time) merged into a single 
basin, once the sedimentary pile was thick enough to cover the ridge that separated the two.

\subsection{Marine Connection to Eastern Australia}

The Early Jurassic sediments of eastern Australia are typically considered to be dominantly non-marine. Though, the Helby beds in the Carpentaria Basin and the oolitic ironstone layers in the Nambour, Surat, and Clarence-Moreton are considered to be indicators of periodic marine incursion into the basins by some workers (e.g., Exon, 1976; Bradshaw and Yeung, 1990; Green et al., 1997). The dominance of 'continental style' deposition has been used as evidence that Australia was landlocked deep within eastern Gondwana. This is partially a function of the lack of data from offshore Queensland; no drill holes have intersected significant Jurassic sections, and most interpretations are built from seismic data (Pinchin and Hudspeth, 1975; Taylor and Falvey, 1977; Mutter and Karner, 1980). However, facies distribution patterns suggest that the depositional systems in the Early Jurassic ultimately flowed toward the east and northeast (Figs. 12-16). Further support for this is derived from the ironstone maps that show increasing thickness and number of ironstone bands towards the north and east, respectively (Fig. 17), suggesting that marine influence was greater in those directions. Recent work by Vink et al. (in review) supports this interpretation, showing that the water in the Precipice Sandstone aquifer flowing towards the Clarence-Moreton Basin in the east. This implies continuity of a transmissive aquifer equivalent to the Precipice Sandstone (i.e., the Ripley Road Sandstone) that is connected through a corridor, and which ultimately discharges at Toowoomba, Queensland - east of the Surat Basin. Various outcrop exposures of the Gatton Sandstone (partially equivalent to the Precipice Sandstone) within that corridor show storm reworking of these deposits (Fig. 18).

Jones and Veevers (1983) proposed depositional continuity across a large region of eastern Australia from 200-140 Ma; in particular, they interpreted that the Eromanga, Carpentaria, Surat, and Papuan basins may have been one continuous depositional entity due to similar ages and stratal relationships within the basins. Palynological evidence from the Razorback beds (Playford and Cornelius, 1967) support this 
hypothesis because of their similarity to the Precipice Sandstone. Based on our results we interpret a narrow passage through the central part of the Surat Basin, between tectonically controlled uplifts of the New England Fold belt (Rosenbaum, 2018), as the most obvious potential marine connection fairway between the Surat and adjacent Clarence-Moreton Basin to the east (see Figs. 13A, 14A, 15A, 16A at ca. $27^{\circ}$ latitude present day). The associated deposits may have resembled strait margin sediments due to bi-directional currents and tidal current amplification (Longhitano et al., 2014). However, the paleogeographic depositional extent in the north is poorly constrained because strata shallow towards ground level and a substantial thickness of section has been removed by erosion; nonetheless we interpret that there was also a marine connection to the north and northeast. Future work should focus on stratal relationships with adjacent basins including the Nambour, Clarence-Moreton, and Mulgildie basins, and to look for evidence of previous connection to terranes that now sit at great distances from Australia such as parts of Zealandia.

\subsection{Basin Tectonics}

While the type of Mesozoic basins represented in eastern Australia have been debated (e.g., Veevers et al., 1982; Fielding et al., 1990; Gallagher, 1990; Yago and Fielding, 1996; Babaahmadi et al., 2019), our analysis and results supports the hypothesis that the Surat Basin sediments were deposited landward of a large subduction zone, and thus the basin represents a retroarc foreland configuration. As pointed out by Jones and Veevers (1983), the co-occurrence of labile sediments shed into the basin from the east, and coals through much of the stratigraphic section (i.e., the Middle-Late Jurassic Walloon Coal Measures) is best explained by persistent subsidence, high water tables, rapid sedimentation, and an orogen to the east. Additional morphological evidence for a foreland basin is the asymmetric, long, and narrow geometry, with a steeper dipping eastern margin than western margin. Although no syn-depositional reverse faults have been documented, the base-Precipice unconformity may be evidence for tectonically-driven basin formation. Jones and Veevers (1983) inferred that the location of the plate boundary was approximately 200 $\mathrm{km}$ east of its present location offshore Queensland, parallel to the east coast of 
Australia and extended north to Papua New Guinea and south past Tasmania to the Transantarctic Mountain terrane. North of $30^{\circ} \mathrm{S}$ present latitude the plate boundary was primarily convergent and was likely the result of ridge push from growth of the Pacific Plate (Bartonlini and Larson, 2001; Seton et al., 2012; Babaahmadi et al., 2019). The sedimentological, stratigraphic, and facies distribution pattern in the context of marine influence support this interpretation. Volcanic detritus in the Surat and ClarenceMoreton basins also support a convergent boundary to the east of present day Queensland (Korsch and Harrington, 1981).

\section{Conclusions}

The combined results of core, wireline log, as well as $2 \mathrm{D}$ and $3 \mathrm{D}$ seismic to produce facies maps has allowed some important conclusions to be made regarding the evolution of depositional environments and paleogeography for the Early Jurassic in the Surat Basin of eastern Australia:

1) The Precipice Sandstone and Evergreen Formation record three $3^{\text {rd }}$-order depositional sequences that were controlled, in part, by global sea level cycles.

2) Deposition was manifest in braidplain systems for the Precipice Sandstone, and fluvio-deltaic depositional systems for the Evergreen Formation. Near the top of the Evergreen Formation, within the Westgrove Ironstone Member, brackish to shallow-marine conditions were fully established within large portions of the basin.

3) Marine influence became increasingly more prominent up section, though it occurred in discrete pulses derived from a combination of autogenic (i.e., lobe switching, channel avulsion) and allogenic (base level fluctuation due to tectonics or eustasy) control. The most plausible connection to the marine occurred through a narrow passage across the Kumbarilla Ridge to the Clarence-Moreton Basin and / or northwards of the outcrop belt connecting the Surat Basin to the Carpentaria and Papuan basins.

4) Initiation of sedimentation into the Surat Basin occurred in two distinct depositional sub-basins - one in the north central region and one further south. As sedimentation continued these sub-basins merged. 
5) In the early stages of basin fill, the main sediment provenance was the Wunger Ridge and Roma Shelf on the western basin margin. The Moonie-Goondiwindi Fault System on the east was a secondary sediment source. During later stages, sediment input from the southeast increased at the same time as the northeastern basin margin was being transgressed. This resulted in overall decreasing importance of the northeast as a source of sediment input.

6) Sedimentological, stratigraphic, and morphological evidence supports the interpretation that the Surat Basin was a foreland basin, with the associated subduction zone occurring to the east of the present day Queensland coast. This proximity to subduction provided the mechanism for the creation of accommodation space.

The results taken together illustrate a picture of eastern Gondwana that challenges a commonly held view that it was locked in an intracratonic setting, far from the influence of eustasy. Rather, we suggest that eastern Australia was much more dynamic than previously considered and contained a complex mixture of sedimentary environments and paleogeographic orientations such that there was an interplay between fluvial, deltaic, and shallow marine depositional systems. Our series of facies maps provide a foundation upon which future workers can examine the stratigraphic relationships between the Surat Basin and other eastern Australian basins to improve our understanding of the evolution of Gondwana during the Jurassic. Finally, the dataset and results can be used by geoscientists working in other basins globally as an analogue for understanding the complex interplay of paralic depositional systems in data poor areas.

\section{Acknowledgements}

This project was funded by the Australian Government, through the Carbon Capture and Storage Research Development and Demonstration Fund (CCS RD\&D), Australian Coal Association Low Emissions Technology (ACALET), and the University of Queensland. We thank the staff from the Department of Natural Resources, Mines, and Energy (DMRME) Exploration Data Centre in Zillmere, Queensland for providing 
access to core. We also acknowledge Australia Pacific LNG (APLNG), Carbon Transport and Storage Company (CTSCo), Origin Energy, and Queensland Gas Company (QGC) for data access. Joan Esterle is thanked for her wealth of insight passed along during days in the field and lab. Early discussions with Mark Reilly and Andrew Garnett helped form the context for the study. We also thank Associate Editor Adam McArthur, Mike Martin, John McKellar, and Carmine Wainman for constructive reviews that greatly improved the final version of the paper. 


\section{References}

Ainsworth, R.B., Vakarelov, B.K., Lee, C., MacEachern, J.A., Montgomery, A.E., Ricci, L.P. and Dashtgard, S.E. (2015) Architecture and evolution of a regressive, tideinfluenced marginal marine succession, Drumheller, Alberta, Canada. Journal of Sedimentary Research, 85, 596-625.

Babaahmadi, A., Uysal, I.T. and Rosenbaum, G. (2019) Late Jurassic intraplate faulting in eastern Australia: a link to subduction in eastern Gondwana and plate tectonic reorganisation. Gondwana Research, 66, 1-12.

Baniak, G.M., Gingras, M.K., Burns, B.A. and Pemberton, S.G. (2014) An example of a highly bioturbated, storm-influenced shoreface deposit: Upper Jurassic Ula Formation, Norwegian North Sea. Sedimentology, 61, 1261-1285.

Bartonlini, A. and Larson, R.L. (2001) Pacific microplate and the Pangea supercontinent in the Early to Middle Jurassic. Geology, 29, 735-738.

Bauch, H.A., Kassens, H., Erlenkeuser, H., Groots, P.M. and Theide, J. (1999) Depositional environment of the Laptev Sea (Arctic Siberia) during the Holocene. Boreas, 28, 194-204.

Bianchi, V., Zhou, F., Pistellato, D., Martin, M., Boccardo, S. and Esterle, J. (2018) Mapping a coastal transition in braided systems: an example from the Precipice Sandstone, Surat Basin. Australian Journal of Earth Sciences, 65, 483-502.

Bomfleur, B., Schoner, R., Schneider, J.W., Viereck, L., Kerp, H. and McKellar, J.L. (2014) From the Transantarctic Basin to the Ferrar Large Igneous Province-New palynostratigraphic age constraints for Triassic-Jurassic sedimentation and magmatism in East Antarctica. Review of Palaeobotany and Palynology, 207, 18-37.

Bradshaw, M. and Yeung, M. 1990. The Jurassic palaeogeography of Australia. Bureau of Mineral Resources, Australia, Record 1990/76, Palaeogeography 26, 60p.

Bradshaw, M. and Yeung, M. (1992) Palaeogeographic Atlas of Australia, Volume 8 Jurassic, Department of Primary Industries and Energy, Australian Geological Survey Organization (AGSO), Australian Government Publishing Service, Canberra, 36 pp.

Bradshaw, M.T. and Challinor, A.B. (1992) Regional geology and stratigraphyAustralasia. In: The Jurassic of the circum-Pacific (Ed G.E.G. Westermann), pp. 162180. Cambridge University Press, Cambridge.

Burbank, D.W. and Verges, J. (1994) Reconstruction of topopgraphy and related depositional systems during active thrusting. Journal of Geophysical Research, 99, 20,281-20,297. 
Burke, K. (2011) Plate tectonics, the Wilson Cycle, and mantle plumes: geodynamics from the top. Annual Review of Earth and Planetary Sciences, 39, 1-29.

Carboni, M.G., Bergamin, L., Di Bella, L., Esu, D., Cerone, E.P., Antonioli, F. and Verrubbi, V. (2010) Palaeoenvironmental reconstruction of late Quaternary foraminifera and molluscs from the ENEA borehole (Versilian plain, Tuscany, Italy). Quaternary Research, 74, 265-276.

Cawood, P.A., Hawkesworth, C.J., Pisarvesky, S.A., Dhuime, B., Capitanio, F.A. and Nebel, O. (2018) Geological archive of the onset of plate tectonics. Philosophical Transactions of the Royal Society A: Mathematical, Physical and Engineering Sciences, 376, 1-30.

Cosgrove, J.L. and Mogg, W.G. (1985) Recent exploration and hydrocarbon potential of the Roma Shelf, Queensland. Australian Petroleum Exploration Association (APEA) Journal, 25, 216-234.

Cranfield, L.C., Carmichael, B.C. and Wells, A.T. (1994) Ferruginous oolite and associated lithofacies from the Clarence-Moreton and related basins in southeast Queensland. In: Geology and petroleum poetential of the Clarence-Moreton Basin, New South Wales and Queensland (Eds A.T. Wells and R.E. O'Brien), 241, pp. 144-163. Australian Geological Survey Organisation.

de Jersey, N.J. and McKellar, J.L. (2013) The palynology of the Triassic-Jurassic transition in southeastern Queensland, Australia, and correlation with New Zealand. Palynology, 37.

DeCelles, P.G., Kapp, P., Ding, L. and Gehrels, G.E. (2007) Late Cretaceous to middle Tertiary basin evolution in the central Tibetan Plateau: changing environments in response to tectonic partitioning, aridification, and regional elevation gain. GSA Bulletin, $199,654-680$.

Deveugle, P.E.K., Jackon, M.D., Hampson, G.J., Stewart, J., Clough, M.D., Ehighebolo, T., Farrell, M.E., Calvart, C.S. and Miller, J.K. (2014) A comparative study of reservoir modeling techniques and their impact on predicted performance of fluvial-dominated deltaic reservoirs. AAPG Bulletin, 98, 729-763.

Dickins, J.M. and Malone, E.J. 1973. Geology of the Bowen Basin, Queensland. Canberra ACT: Bureau of Mineral Resources, Geology and Geophysics, Bulletin 130, $154 \mathrm{p}$.

Eganhouse, R.P. and Kaplan, I.R. (1988) Depositional history of Recent sediments from San Pedro Shelf, California: reconstruction using elemental abundance, isotopic composition and molecular markers. Marine Chemistry, 24, 163-191. 
Ellison, S.P. (1951) Microfossils as environment indicators in marine shales. Journal of Sedimentary Research, 21, 214-225.

Evans, P.R. 1962. Microfossils association with the "Bundamba Group" of the Surat Bain, Queensalnd, Department of National Development, Bureau of Mineral Resources Geology and Geophysics, Canberta, ACT.

Exon, N.F. 1976. Geology of the Surat Basin in Queensland. Canberra ACT: Bureau of Mineral Resources, Australia, Bulletin, 166, 200 p.

Exon, N.F. and Burger, D. (1981) Sedimentary cycles in the Surat Basin and global changes in sea level. BMR Journal of Australian Geology and Geophysics, 6, 153-159.

Exon, N.F. and Senior, B.R. (1976) The Cretaceous of the Eromanga and Surat basins. BMR Journal of Australian Geology and Geophysics, 1, 33-50.

Fastovsky, D.E. (1987) Paleoenvironments of Vertebrate-Bearing Strata during the Cretaceous-Paleogene Transition, Eastern Montana and Western North Dakota. Palaios, 2, 282-295.

Fielding, C.R. (1996) Mesozoic sedimentary basins and resources in eastern Australia - a review of current understanding. In: Mesozoic Geology of the Eastern Australia Plate Conference, Extended Abstracts 43, pp. 180-185. Geological Society of Australia, Brisbane, Queensland.

Fielding, C.R., Gray, A.R.G., Harris, G.I. and Saloman, J.A. (1990) The Bowen Basin and overlying Surat Basin. In The Eromanga-Brisbane Geoscience Transect: a Guide to Basin Development across Phanerozoic Australia in Southern Queensland (Ed D.M. Finlayson). Bureau of Mineral Resources, Geology and Geophysics, Australia, Bulletin, 232, 105-116.

Frakes, L.A., Burger, D., Apthorpe, M., Wiseman, J., Dettmann, M., Alley, N., Flint, R., Gravestock, D., Ludbrook, N., Backhouse, J., Skwarko, S., Scheibnerova, V., McMinn, A., Moore, P.S., Bolton, B.R., Douglas, J.G., Christ, R., Wade, M., Molnar, R.E., McGowran, B., Balme, B.E. and Day, R.A. (1987) Australian Cretaceous shorelines, stage by stage. Palaeogeography, Palaeoclimatology, Palaeoecology, 59, 31-48.

Gallagher, K. (1990) Permian-Cretaceous subsidence history along the Eromanga Brisbane geoscience transect In The Eromanga-Brisbane Geoscience Transect: a Guide to Basin Development across Phanerozoic Australia in Southern Queensland (Ed D.M. Finlayson). Bureau of Mineral Resources, Geology and Geophysics, Australia, Bulletin, 232, 133-151.

Gallagher, K., Dumitru, T.A. and Gleadow, A.J.W. (1994) Constraints on the vertical motion of eastern Australia during the Mesozoic. Basin Research, 6, 77-94. 
Gingras, M.K., Pemberton, S.G., Saunders, T. and Clifton, H.E. (1999) The ichnology of modern and Pleistocene brackish-water deposits at Willapa Bay, Washington: variability in estuarine settings. Palaios, 14, 352-374.

Gray, A.R.G. 1968. Stratigraphic drilling in the Surat and Bowen Basins, 1965-66. Geological Survey of Queensland, Report 22, 34 pp.

Green, P.M., Hoffmann, K.L., Brain, T.J. and Gray, A.R.G. 1997. The Surat and Bowen Basins, south-east Queensland, Queensland Minerals and Energy Review Series, Queensland Department of Mines and Energy, Brisbane, 238 pp.

Hallam, A. (1975) Jurassic Environments. Cambridge University Press, 269 pp. Haq, B.U., Hardenbol, J. and Vail, P.R. (1987) Chronology of fluctuating sea levels since the Triassic. Science, 235, 1156-1167.

He, J., La Croix, A.D., Wang, J., Ding, W. and Underschultz, J.R. (2019) Using neural networks and the Markov Chain approach for facies analysis and prediction from well logs in the Precipice Sandstone and Evergreen Formation, Surat Basin, Australia. Marine and Petroleum Geology, 101, 410-427.

He, J.H., Ding, W.L., Jiang, Z.X., Li, A., Wang, R.Y. and Sun, Y.X. (2016) Logging identification and characteristic analysis of the lacustrine organic-rich shale lithofacies: a case study from the Es3l shale in the Jiyang Depression, Bohai Basin, Eastern China. Journal of Petroleum Science and Engineering, 145, 238-255.

Hoffmann, K.L., Totterdell, J.M., Dixon, O., Simpson, G.A., Brakel, A.T., Wells, A.T. and Mckellar, J.L. (2009) Sequence stratigraphy of Jurassic strata in the lower Surat Basin succession, Queensland. Australian Journal of Earth Sciences, 56, 461-476.

Howell, J.A., Martinius, A.W. and Good, T.R. (2014) The application of outcrop analogues in geological modelling: a review, present status and future outlook. 387, SP387.12.

Ingersoll, R.V. (2012) Tectonics of sedimentary basins, with revised nomenclature. In: Tectonics of Sedimentary Basins: Recent Advances (Eds C.J. Busby and A. Azor), pp. 3-43. Blackwell Publishing Ltd., Oxford, UK.

Jell, P.A. (2013) Geology of Queensland. Geological Survey of Queensland, Brisbane, $970 \mathrm{pp}$.

Jiang, L. and George, S.C. (2018) Biomarker signatures of Upper Cretaceous Latrobe Group hydrocarbon source rocks, Gippsland Basin, Australia: distribution and palaeoenvironment significance of aliphatic hydrocarbons. International Journal of Coal Geology, 196, 29-42. 
Jones, J.G. and Veevers, J.J. (1983) Mesozoic origins and antecedents of Australia's Eastern Highlands. Journal of the Geological Society of Australia, 30, 305-322.

Jones, M.T., Dashtgard, S.E. and MacEachern, J.A. (2018) A conceptual model for the preservation of thick, transgressive shoreline successions: examples from the foreac Naniamo Basin, British Columbia, Canada. Journal of Sedimentary Research, 88, 811-826.

Korsch, R.J. and Harrington, H.J. (1981) Stratigtaphic and structural synthesis of the New England Orogen. Journal of the Geological Society of Australia, 28, 205-226.

Korsch, R.J., O'Brien, P.E., Sexton, M.J., Wake-Dyster, K.D. and Wells, A.T. (1989) Development of Mesozoic transtensional basins in easternmost Australia. Australian Journal of Earth Sciences, 36, 13-28.

Korsch, R.J. and Totterdell, J.M. (2009) Subsidence history and basin phases of the Bowen, Gunnedah and Surat Basins, eastern Australia. Australian Journal of Earth Sciences, 56, 335-353.

Kutzbach, J.E. and Gallimore, R.G. (1989) Pangaean climates: megamonsoons of the megacontinent. Journal of Geophysical Research, 94, 3341-3357.

La Croix, A.D., Dashtgard, S.E. and MacEachern, J.A. (2019a) Using a modern analogue to interpret depositional position in ancient fluvial-tidal channel complexes: an example from the McMurray Formation, Canada. Geoscience Frontiers, 36 pp.

La Croix, A.D., Gingras, M.K., Pemberton, S.G., Mendoza, C.A., MacEachern, J.A. and Lemiski, R.T. (2013) Biogenically enhanced reservoir properties in the Medicine Hat gas field, Alberta, Canada. Marine and Petroleum Geology, 43, 464-477.

La Croix, A.D., MacEachern, J.A., Ayranci, K., Hsieh, A. and Dashtgard, S.E. (2017) An ichnological-assemblage approach to reservoir heterogeneity assessment in bioturbated strata: Insights from the Lower Cretaceous Viking Formation, Alberta, Canada. Marine and Petroleum Geology, 86, 636-654.

La Croix, A.D., Wang, J., He, J., Hannaford, C., Bianchi, V., Esterle, J.S. and Underschultz, J.R. (2019b) Widespread nearshore and shallow marine deposition within the Lower Jurassic Precipice Sandstone and Evergreen Formation in the Surat Basin, Australia. Marine and Petroleum Geology, 109, 760-790.

Lech, M.E., Jorgensen, D.C., Southby, C., Wang, L., Nguyen, V., Borissova, I. and Lescinsky, D. (2016) Palaeogeographic mapping to understand the hydrocarbon and $\mathrm{CO} 2$ storage potential of the post-rift Warnbro Group, offshore Vlaming Sub-basin, southern Perth Basin, Australia. Marine and Petroleum Geology, 77, 1206-1226. 
Longhitano, S.G., Chiarella, D. and Muto, F. (2014) Three-dimensional to two-dimensional cross-strata transition in the lower Pleistocene Catanzaro tidal strait transgressive succession (southern Italy). Sedimentology, 61, 2136-2171.

Martin, K.R. (1981) Deposition of the Precipice Sandstone and the evolution of the Surat Basin in the Early Jurassic. The APPEA Journal, 21, 16-23.

Martin, M.A., Wakefield, M., Bianchi, V., Esterle, J. and Zhou, F. (2018) Evidence for marine influence in the Lower Jurassic Precipice Sandstone, Surat Basin, eastern Australia. Australian Journal of Earth Sciences, 65, 75-91.

McDougall, I. (2008) Geochronology and the evolution of the Australia in the Mesozoic. Australian Journal of Earth Sciences, 55, 849-864.

McKellar, J.L. (1998) Late Early to Late Jurassic palynology, biostratigraphy and palaeogeography of the Roma Shelf area, northwestern Surat Basin, Queensland, Australia, University of Queensland, Brisbane, Queensland, 620 pp.

McKellar, J.L. (2004) Geophysical controls on late Palaeozoic - early Mesozoic geological history and floral succession: eastern Australia in perspective. Association of Australasian Palaeontologists Memoir, 29, 47-83.

Mollan, R.G., Dickins, J.M., Exon, N.F., and Kirkegaard, A.G. (1969) Geology of the Springsure 1:250 000 Sheet area, Queensland. Bureau of Mineral Resources, Geology and Geophysics, Australia, Report 123.

Mollan, R.G., Forbes, V.R., Jensen, A.R., Exon, N.F. \& Gregory, C.M. (1972) Geology of the Eddystone, Taroom and western part of the Mundubbera Sheet areas, Queensland. Bureau of Mineral Resources, Geology and Geophysics, Australia, Report 142.

Mutter, J.C. and Karner, G.D. (1980) The continental margin off northeast Australia. In: The Geology and Geophysics of Northeast Australia (Eds R.A. Henderson and P.J. Stephenson), pp. 47-69. Geological Society of Australia (Queensland Division), Brisbane.

Nyberg, B. and Howell, J.A. (2016) Global distribution of modern shallow marine shorelines. Implications for exploration and reservoir analogue studies. Marine and Petroleum Geology, 71, 83-104.

Pilarczyk, J.E., Dura, T., Horton, B.P., Engelhart, S.E., Kemp, A.C. and Sawai, Y. (2014) Microfossils from coastal environments as indicators of paleo-earthquakes, tsumanis and storms. Palaeogeography, Palaeoclimatology, Palaeoecology, 413, 144157. 
Pinchin, J. and Hudspeth, J.W. (1975) The Queensland Trough: its petroleum potential based on some recent geophysical results. APPEA Journal, 15, 21-31.

Playford, G. and Cornelius, K.D. (1967) Palynological and lithostratigraphic features of the Razorback Beds, Mount Morgan district, Queensland. Department of Geology, University of Queensland, Papers 6(3), 81-94.

Postma, G. (2001) Physical climate signatures in shallow- and deep-water deltas. Global and Planetary Change, 28, 93-106.

Power, P.E. and Devine, S.B. (1970) Surat Basin, Australia - subsurface stratigraphy, history, and petroleum. American Association of Petroleum Geologists Bulletin, 54, 2410-2437.

Quilty, P.G. (1984) Mesozoic and Cenozoic history of Australia as it affects the Australian biota. In: Arid Australia (Eds H.G. Cogger and E.E. Cameron), pp. 7-55. Australian Museum, Sydney.

Raza, A.. Jill, K.C., and Korsch, R.J. (2009) Mid-Cretaceous uplift and denudation of the Bowen and Surat basins, eastern Asutralia: relationship to Tasman Sea rifting from apatite fission-track and vitrinite-reflectance data. Australian Journal of Earth Sciences, 56, 501-531.

Reiser, R.F. and Williams, A.J. 1969. Palynology of the Lower Jurassic sediments of the northern Surat Basin, Queensland, Geological Survey of Queensland Brisbane, Queensland.

Rosenbaum, G. (2018) The Tasmanides: Phanerozoic tectonic evolution of eastern Australia. Annual Review of Earth and Planetary Sciences, 46, 291-325.

Schmidt, P.W. and Clark, D.A. (2000) Paleomagnetism, apparent polarwander path, and paleolatitude. In: Billion-year Earth History of Australia and Neighbours in Gondwanaland (Ed J.J. Veevers), pp. 12-17. GEMOC Press, Sydney.

Scotese, C.R. and McKerrow, W.S. (1990) Revised world maps and introduction. Geological Society of London Memoirs, 12, 1-21.

Sell, B.H., Brown, L.N. and Groves, R.D. (1972) Basal Jurassic sands of the Roma area. Queensland Government Mining Journal, 73, 309-321.

Seton, M., Muller, R.D., Zahirovic, S., Gaina, C., Torsvik, T., Shepard, G., Talsma, A., Gurnis, M., Turner, N., Maus, S. and Chandler, M. (2012) Global continenetal and ocean basin reconstructions since $200 \mathrm{Ma}$. Earth-Science Reviews, 113, 212-270.

Shu, L., Faure, M., Jiang, S., Yang, Q. and Wang, Y. (2006) SHRIMP zircon U-Pb age, litho- and biostratigraphic analyses of the Huaiyu Domain in South China - 
evidence for a Neoproterozoic orogen, not Late Paleozoic-Early Mesozoic collision. Episodes, 29, 244-252.

Struckmeyer, H.I. and Totterdell, J.M. (1990) Australia: Evolution of a continent. Australian Government Publishing Service, Canberra, ACT.

Taylor, L.W.H. and Falvey, D.A. (1977) Queensland Plateau and Coral Sea Basin: stratigraphy, structure and tectonics. APPEA Journal, 17, 13-29.

Totterdell, J.M., Moloney, J., Korsch, R.J. and Krassay, A.A. (2009) Sequence stratigraphy of the Bowen-Gunnedah and Surat basins in New South Wales. Australian Journal of Earth Sciences, 56, 433-459.

Turner, S., Bean, L.B., Dettmann, M., McKellar, J.L., McLoughlin, S. and Thulborn, T. (2009) Australian Jurassic sedimentary and fossil successions: current work and future prospects for marine and non-marine correlation. GFF, 131, 49-70.

Veevers, J.J. (1984) Phanerozoic Earth History of Australia. Claredon Press, Oxford, UK. 418 pp.

Veevers, J.J. (2000) Billion-Year Earth History of Australia and Neighbours in Gondwanaland. GEMOC Press, Sydney, Australia, 400 pp.

Veevers, J.J. (2004) Gondwanaland from 650-500 Ma assembly through $320 \mathrm{Ma}$ merger in Pangea to 185-100 Ma breakup: supercontinental tectonics via stratigraphy and radiometric dating. Earth-Science Reviews, 68, 1-32.

Veevers, J.J. (2006) Updated Gondwana (Permian-Cretaceous) earth history of Australia. Gondwana Research, 9, 231-260.

Veevers, J.J., Jones, J.G., Powell, C.M. and Talent, J.A. (1984) Synopsis. In: Phanerozoic earth history of Australia (Ed J.J. Veevers), pp. 351-402. Claredon Press, Oxford.

Veevers, J.J., Jones, J.R. and Powell, C.M. (1982) Tectonic framework of Australia's sedimentary basins. Australian Petroleum Exploration Association Journal, 22, 283-300.

Viseras, C., Soria, J.M., Duran, J.J., Pla, S., Garrido, G., Garcia-Garcia, F. and Arribas, A. (2006) A large-mammal site in a meandering fluvial context (Fonelas P-1, Late Pliocene, Guadix Basin, Spain): Sedimentological keys for its paleoenvironmental reconstruction. Palaeogeography, Palaeoclimatology, Palaeoecology, 242, 139-168.

Wainman, C.C. and McCabe, P.J. (2018) Evolution of the depositional environments of the Jurassic Walloon Coal Measures, Surat Basin, Queensland, Australia.

Sedimentology, 1-27. 
Wainman, C.C., McCabe, P.J., and Crowley, J.L. (2018) Solving a tuff problem: defining a chronostratigraphic framework for the Middle to Upper Jurassic nonmarine strata in eastern Australia using uranium-lead chemical abrasian-thermal ionization mass spectrometry zircon dates. AAPG Bulletin, 102, 1141-1168.

Wang, C., Feng, Z., Zhang, L., Huang, Y., Cao, K., Wang, P. and Zhao, B. (2013) Cretaceous paleogeography and paleoclimate and the setting of SKI borehold sites in Songlio Basin, northeast China. Palaeogeography, Palaeoclimatology, Palaeoecology, $385,17-30$.

Wang, G.C. and Timothy, R.C. (2013) Organic-rich Marcellus Shale lithofacies modelling and distribution pattern analysis in the Appalachian Basin. AAPG Bulletin, 97.

Wang, J., La Croix, A.D., Gonzalez, S., He, J. and Underschultz, J.R. (2019) Sequence stratigraphic analysis of the Lower Jurassic Precipice and Evergreen Formations in the Surat Basin, Australia: implications for the architecture of reservoirs and seals for CO2 storage. Marine and Petroleum Geology, 102, 829-843.

Waschbusch, P., Korsch, R.J. and C., B. (2009) Geodynamic modelling of aspects of the Bowen, Gunnedah, Surat and Eromanga Basins from the perspective of convergent margin processes. Australian Journal of Earth Sciences, 56, 309-334.

Wells, A.T., Brakel, A.T., Totterdell, J.M., Korsch, R.J. and Nicoll, R.S. 1994. Sequence stratigraphic interpretation of seismic data north of $26^{\circ} \mathrm{S}$, Bowen and Surat basins, Queensland, Marine, Petroleum, and Sedimentary Resources Division, Canberra, ACT.

Wilson, J.T. (1968) Static or mobile Earth: the current scientific revolution. Proceedings of the American Philosophical Society, 112, 309-320.

Wooldridge, C.L. and Hickin, E.J. (2005) Radar architecture and evolution of channel bars in wandering gravel-bed rivers: Fraser and Squamish Rivers, British Columbia, Canada. Journal of Sedimentary Research, 75, 844-860.

Yago, J.V.R. and Fielding, C.R. (1996) Sedimentology of the Middle Jurassic Walloon Coal Measures in the Great Artesian Basin, eastern Australia. In: Mesozoic Geology of the Eastern Australia Plate Conference, Extended Abstracts 43. Geological Society of Australia, Brisbane, Queensland, 574-575.

Zeng, Z., Zhu, H., Yang, X., Zeng, H., Hu, X. and Xia, C. (2019) The Pangaea Megamonsoon records: Evidence from the Triassic Mungaroo Formation, Northwest Shelf of Australia. Gondwana Research, 69, 1-24.

Zhang, K.J., Xia, B.D., Wang, G.M., Li, Y.T. and Ye, H.F. (2004) Early Cretaceous stratigraphy, depositional environments, sandstone provenance, and tectonic setting of central Tibet, western China. GSA Bulletin, 116, 1202-1222. 
Zhu, X., Zeng, H., Li, S., Dong, Y., Zhu, S., Zhao, D. and Huang, W. (2017) Sedimentary characteristics and seismic geomorphologic responses of a shallow-water delta in the Qingshankou Formation from the Songliao Basin, China. Marine and Petroleum Geology, 79, 131-148.

Ziolkowski, V., Hodgkinson, J., McKillop, M., Grigorescu, M. and McKellar, J.L. 2014. Sequence stratigraphic analysis of the Lower Jurassic succession in the Surat Basin, Queensland - preliminary findings, Queensland Minerals and Energy Review Series, Department of Natural Resources and Mines, Queensland, 24 pp. 


\section{Figure and Table Captions}

Table 1 - Core facies and wireline log facies classification of the Precipice Sandstone and Evergreen Formation in the Surat Basin. Data from He et al. (2019) and La Croix et al. (2019b).

Figure 1 - Broad-scale paleo-depositional environment maps for the Early Jurassic from Yeung and Bradshaw (1990). (A) "Jurassic 1" (earliest Jurassic map). (B) "Jurassic 2". (C) "Jurassic 3".

Figure 2 - The position of Australia within Gondwana at 201.6 Ma (Paleoglobe for the Early Jurassic, 201.6 million years ago, by C.R. Scotese, PALEOMAP PROJECT).

Figure 3 - The geographic location (inset) and major structural elements of the Surat Basin in eastern Australia. Black dots indicate the location of cored drill holes that were analyzed in this study. The red dot indicates the location of Woleebee Creek GW4 - our type well for the Precipice-Evergreen interval. The grey dashed box shows the area displayed in the maps from Figures 5, 8, 9, and 11-16. The location of the seismic section from Figure 7 is shown in red.

Figure 4 - Stratigraphic nomenclature of the Lower Jurassic in the Surat Basin. The lithostratigraphy is after McKellar (1998), the sequence stratigraphy is per our study, and the global sea level curves are from Haq et al. (1987). The red line represents the long term eustatic curve, while the blue line indicates the short term changes in eustacy. The sequence stratigraphy consists of three $3^{\text {rd }}$ order sequences (SQ1-SQ3), and is subdivided into systems tracts by the sequence boundaries $\mathrm{J} 10, \mathrm{SB} 2, \mathrm{~J} 20$, and $\mathrm{J} 30$, the transgressive surfaces TS1 and TS3, and the maximum flooding surfaces MFS1 and MFS3. Notably, SQ2 was not subdivided into systems tracts due to its very thin preservation across the basin; SQ2 represents a relatively minor stratal package and no systems tracts were defined within it. 
Figure 5 - Well locations for wireline log facies (WLF) predictions using neural networks (circles), and the cored drill holes that were used to train the neural networks (squares). The colour of the circles represents the number of different wireline logs that each well had available to use in the WLF predictions. Generally, the greater the number of logs, the better the WLF prediction accuracy.

Figure 6 - North-south (A-A') and east-west (B-B', C-C', D-D') oriented wireline log cross sections showing the correlation of sequence stratigraphic surfaces across the basin. The cross section uses the MFS3 surface as the datum. Wireline log facies from core and predicted from neural networks are shown next to each well. Inset map shows the location of cross sections. The dashed grey box indicates the location of maps relative to the basin.

Figure 7 - An east-west trending seismic section tied to Woleebee Creek GW4 showing the three main reflectors within the Precipice-Evergreen succession that have significant lateral continuity across the north-central part of the Surat Basin. Seismic Event 5 broadly corresponds to the J10 surface (sub-Surat unconformity), Seismic Event 4 approximates the top of the Precipice Sandstone (i.e., TS1), and Seismic Event 2 is roughly equivalent to the top of the Boxvale Sandstone (i.e., TS3). The seismic section clearly shows the onlap of the Precipice Sandstone (Lowstand Systems Tract 1) against the $\mathrm{J} 10$ unconformity. The seismic section is displayed in zero phase with SEGY conventional polarity. Truncation and onlap seismic reflector termination styles are indicated, along with interpreted faults.

Figure 8 - Structural elevation maps for the sequence stratigraphic surfaces from the Precipice Sandstone and Evergreen Formation across the Surat Basin: (A) J10 / basePrecipice unconformity; (B) TS1; (C) MFS1; (D) SB2; (E) TS3; (F) J30. White circles show the locations of drill holes used to constrain the stratigraphy. The contour interval is $200 \mathrm{~m}$. See Figure 2 for location of maps. 
Figure 9 - Thickness maps for the main intervals analyzed for the Precipice Sandstone and Evergreen Formation in the Surat Basin: (A) J10-TS1; (B) TS1-MFS1; (C) MFS1SB2; (D) SB2-TS3; (E) TS3-J30. The Northern and Southern sub-basins are correspondingly labelled. White circles show the locations of drill holes used to constrain the stratigraphy. The contour interval is $20 \mathrm{~m}$. See Figure 2 for location of maps.

Figure 10 - (A) Core Facies 4 from Woleebee Creek GW4, 1518.50 m; (B) Core Facies 5 from Woleebee Creek GW, 1297.25 m; (C) Core Facies 7 from Chinchilla 4, 1107.40 m; (D) Core Facies 8 from Chinchilla 4,1003.75 m; (E) Core Facies 9 from Taroom 17, 336.75 m; (F) Core Facies 10 from Chinchilla 4; 1026.45 m; (G) Core Facies 11 from Roma 8, 1006.25 m; (H) Core Facies 12 from Kenya East, 1013.40 m; (I) Core Facies 15 from Chinchilla 4, 1036. $87 \mathrm{~m}$. (J) The acritarch Multiplicisphaeridium spp. from Woleebee Creek GW4, 1336.70 m. (K) Undifferentiated dinocyst from West Wandoan 1, $1011.86 \mathrm{~m}$. $\mathrm{cf}=$ combind flow ripples, $\mathrm{cr}=$ current ripples, $\mathrm{syn}=$ synaeresis cracks, $\mathrm{tm}=$ tempestites, $\mathrm{txb}=$ trough cross beds, $\mathrm{wr}=$ wave ripples, $\mathrm{wu}=$ wavy-undulatory lamination, $\mathrm{Lo}=$ Lockeia, $\mathrm{Pa}=$ Palaeophycus, $\mathrm{PI}=$ Planolites, $\mathrm{Ro}=$ rootlets, $\mathrm{Sc}=$ Scolicia, Te $=$ Teichichnus.

Figure 11 - Detailed core description of the Precipice Sandstone and Evergreen Formation in Woleebee Creek GW4 from $1573.60 \mathrm{~m}$ to $1285.20 \mathrm{~m}$. The descriptions include physical sedimentary structures and accessories, trace fossils and bioturbation intensity, and the sequence stratigraphic sub-division of the core. Core facies (CF) are indicated along with their corresponding wireline logs facies (WLF) sub-divisions.

Figure 12 - (A) Map showing the distribution of depositional environments interpreted from core and wireline logs for the J10-TS1 interval. (B) Palaeocurrent directions for the interval from Martin (1980), Bianchi et al. (2018) and this study. 
Figure 13 - (A) Map showing the distribution of depositional environments interpreted from core and wireline logs for the TS1-MF1 interval. (B) Palaeocurrent directions for the interval from Bianchi et al. (2018) and this study.

Figure 14 - (A) Map showing the distribution of depositional environments interpreted from core and wireline logs for the MFS1-SB2 interval. (B) Palaeocurrent directions for the interval from this study.

Figure 15 - Map showing the distribution of depositional environments interpreted from core and wireline logs for the SB2-TS3 interval. (B) Palaeocurrent directions for the interval from this study.

Figure 16 - Map showing the distribution of depositional environments interpreted from core and wireline logs for the TS3-J30 interval. (B) Palaeocurrent directions for the interval from this study.

Figure 17 - (A) Map showing the number of individual ironstone layers in drill holes. (B) Map displaying the cumulative thickness of ironstone in drill holes. Data were derived from core and wireline logs.

Figure 18 - Swaley cross-beds (i.e., tempestites) from the Gatton Sandstone - a partial equivalent in the Clarence-Moreton Basin to the Precipice Sandstone in the Surat Basin. Location of outcrop is: $27^{\circ} 25.045^{\prime}$ S, $152^{\circ} 20.392^{\prime} \mathrm{E}$. 


\begin{tabular}{|c|c|c|c|c|c|c|}
\hline $\begin{array}{l}\text { Wireline Log Facies } \\
\text { (WLF) }\end{array}$ & $\begin{array}{c}\begin{array}{c}\text { Gamma Ray Log } \\
\text { Motif }\end{array} \\
\end{array}$ & $\begin{array}{l}\text { Core Facies } \\
\text { (CF) }\end{array}$ & Description & Composition & $\begin{array}{c}\text { Thickness } \\
(\mathrm{m})\end{array}$ & Depositional Environment \\
\hline- & - & 1 & Interbedded conglomerate and sandstone & $>30 \%$ granules and coarser & $\begin{array}{c}0.25-1.2 \\
\text { (mean: } 0.83)\end{array}$ & Lag deposit or channel base \\
\hline- & - & 2 & Mud-clast breccia & $>30 \%$ granules and coarser & $\begin{array}{c}0.17-0.8 \\
\text { (mean: } 0.41)\end{array}$ & $\begin{array}{c}\text { Channel base or channel bank } \\
\text { collapse }\end{array}$ \\
\hline SA & $\begin{array}{l}\text { Smooth cylindrical } \\
\text { shape }\end{array}$ & 3 & Coarse-grained planar-tabular cross-bedded sandstone & $>90 \%$ sand & $\begin{array}{l}0.2-77.2 \\
\text { (mean: } \\
12.59 \text { ) }\end{array}$ & Fluvial channel \\
\hline SB & $\begin{array}{l}\text { Smooth concave bell } \\
\text { shape }\end{array}$ & 4 & $\begin{array}{l}\text { Fine-grained planar-tabular grading into current ripple laminated } \\
\text { sandstone }\end{array}$ & $>90 \%$ sand & $\begin{array}{c}0.35-18.7 \\
\text { (mean: } 4.54)\end{array}$ & Distributary channel \\
\hline \multirow[b]{2}{*}{ SC } & $\begin{array}{l}\text { Smooth concave } \\
\text { funnel shape }\end{array}$ & 9 & Wave- to combined-flow ripple laminated sandstone & $>90 \%$ sand & $\begin{array}{c}0.2-10.33 \\
\text { (mean: } 2.26)\end{array}$ & Mouthbar \\
\hline & $\begin{array}{l}\text { Erratic concave funnel } \\
\text { shape }\end{array}$ & 5 & Structureless to planar-parallel laminated sandstone & $>90 \%$ sand & $\begin{array}{c}0.18-4.85 \\
\text { (mean: } 1.30)\end{array}$ & Channel levee or splay \\
\hline SD & $\begin{array}{l}\text { Erratic concave funnel } \\
\text { shape }\end{array}$ & 12 & $\begin{array}{l}\text { Bioturbated muddy sandstone with wave-ripple lamination and HCS } \\
\text { interbeds }\end{array}$ & $>90 \%$ sand & $\begin{array}{l}\text { 1.30-7.12 } \\
\text { (mean: } 3.29 \\
\end{array}$ & Lower shoreface \\
\hline MA & Smooth line shape & 6 & Structureless, carbonaceous siltstone and mudstone & $>90 \%$ silt and clay & $\begin{array}{c}0.12-7.60 \\
\text { (mean: } 1.15)\end{array}$ & Floodplain \\
\hline \multirow[b]{2}{*}{ MB } & Erratic line shape & 8 & Bioturbated muddy sandstone and sandy mudstone & $>90 \%$ silt and clay & $\begin{array}{c}0.23-1.90 \\
\text { (mean: } 0.80)\end{array}$ & Interdistributary Bay \\
\hline & Smooth line shape & 13 & Bioturbated sandy mudstone with wave-ripple to HCS interbeds & $>90 \%$ silt and clay & $\begin{array}{c}0.53-4.13 \\
\text { (mean: } 2.33)\end{array}$ & Upper offshore \\
\hline SMA & $\begin{array}{l}\text { Erratic concave egg } \\
\text { shape }\end{array}$ & 10 & $\begin{array}{l}\text { Sand-dominated to sub-equal sandy and muddy heterolithics } \\
\text { (sandstone and mudstone) }\end{array}$ & $90 \%>$ sand $>30 \%$ & $\begin{array}{l}0.25-5.70 \\
\text { (mean: } 2.08)\end{array}$ & Delta front \\
\hline \multirow[b]{2}{*}{ SMB } & Erratic line shape & 11 & Mud-dominated heterolithics (sandstone and mudstone) & $30 \%>$ sand $>10 \%$ & $\begin{array}{c}0.16-10.6 \\
\text { (mean: } 1.49)\end{array}$ & Prodelta \\
\hline & Erratic line shape & 14 & $\begin{array}{l}\text { Mixed sandy and muddy heterolithics with tide-generated structures } \\
\text { (sandstone and mudstone) }\end{array}$ & $90 \%>$ sand $>10 \%$ & $\begin{array}{l}0.11-5.50 \\
\text { (mean: } 1.54\end{array}$ & Tidal flats \\
\hline OA & $\begin{array}{l}\text { Smooth convex egg } \\
\text { shape }\end{array}$ & 7 & Coal & Predominantly organic macerals & $\begin{array}{c}0.05-0.91 \\
\text { (mean: } 0.22\end{array}$ & Peat mire \\
\hline OB & $\begin{array}{l}\text { Smooth convex egg } \\
\text { shape }\end{array}$ & 15 & Ironstone & $\begin{array}{c}\text { Ironstone ooids (sand sized) or } \\
\text { cemented }\end{array}$ & $\begin{array}{c}0.05-1.35 \\
\text { (mean: } 0.44\end{array}$ & Restricted marine shoals \\
\hline
\end{tabular}




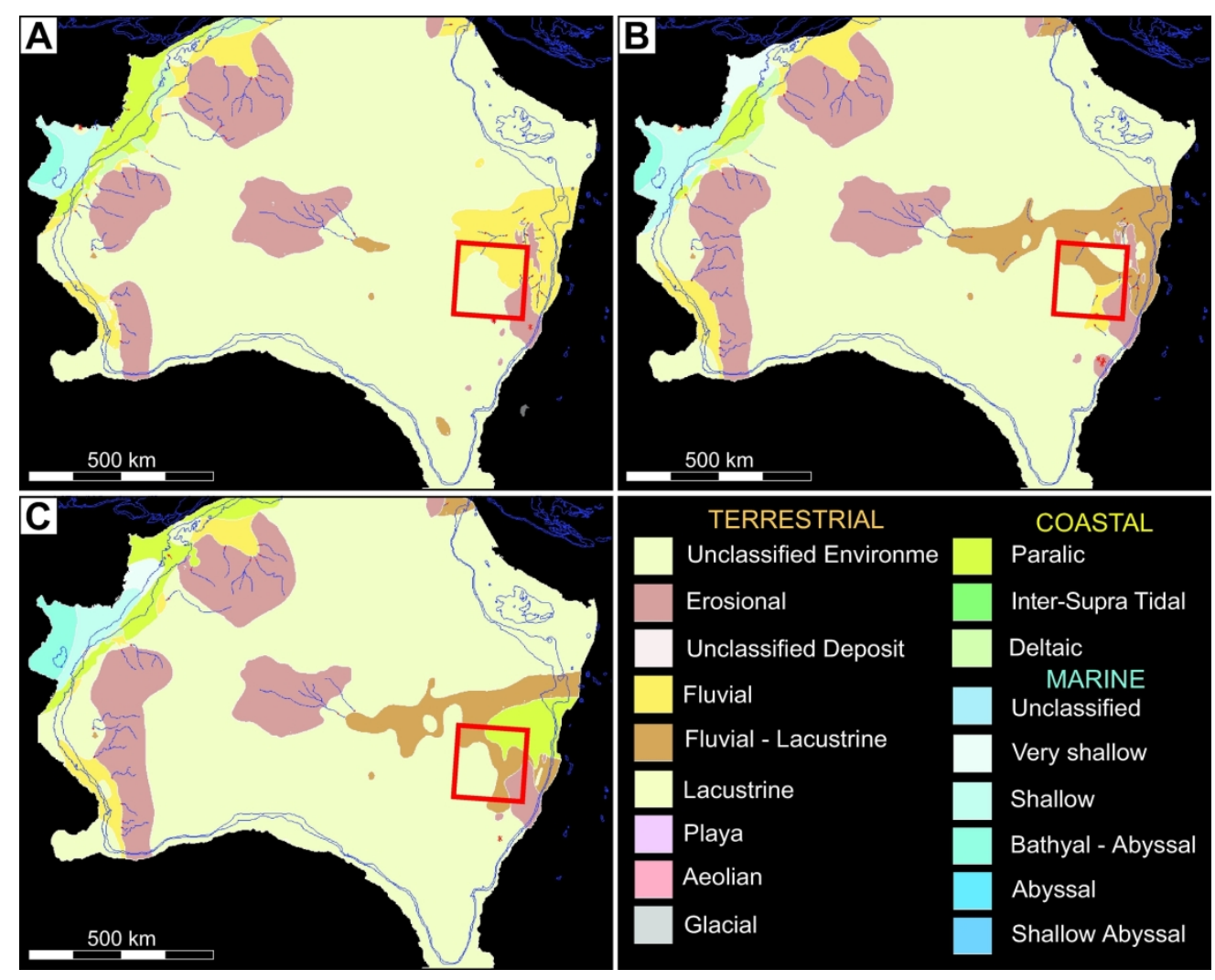

Figure 1

$189 \times 151 \mathrm{~mm}(300 \times 300$ DPI $)$ 


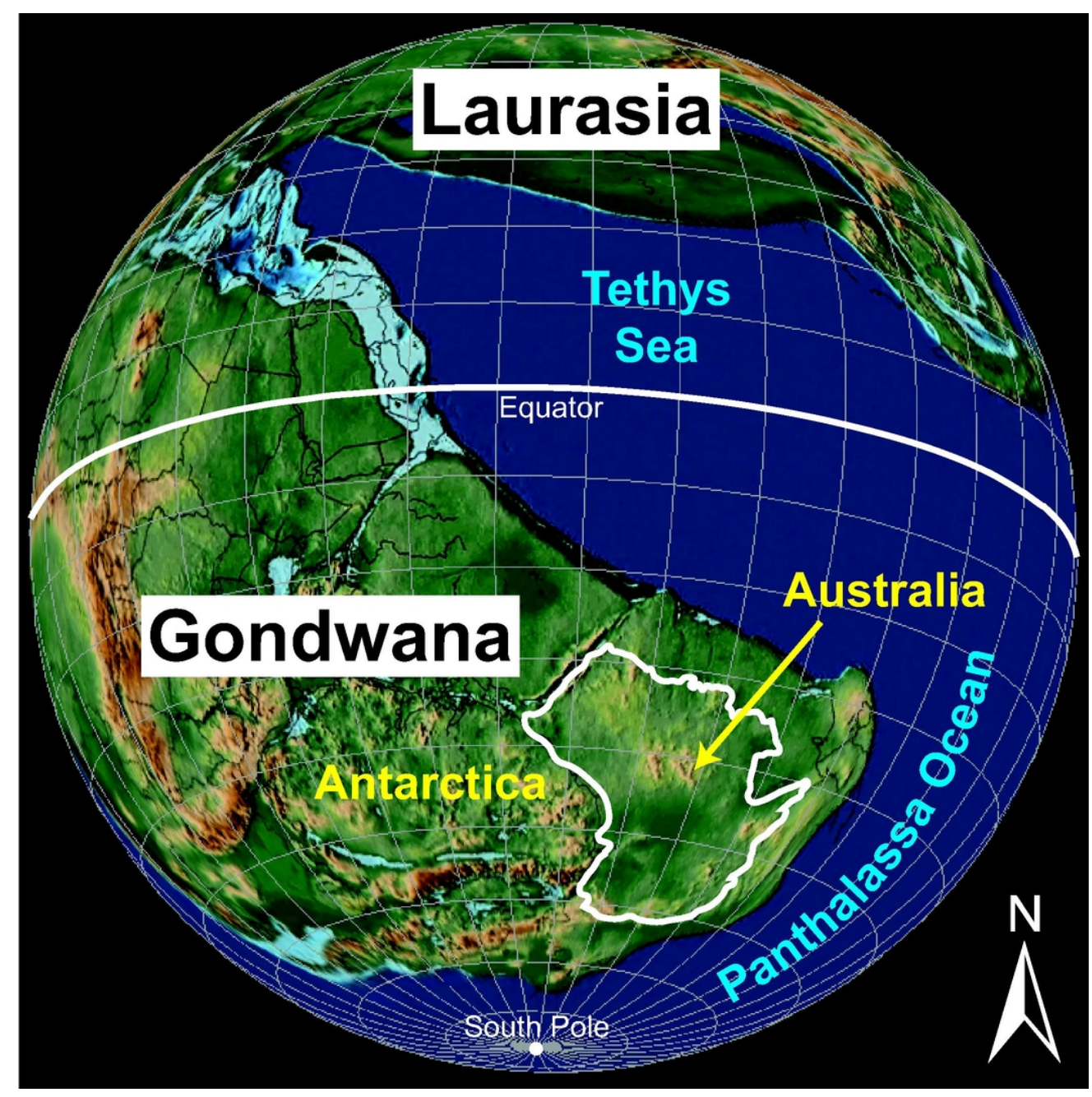

Figure 2

$90 \times 90 \mathrm{~mm}(300 \times 300 \mathrm{DPI})$ 


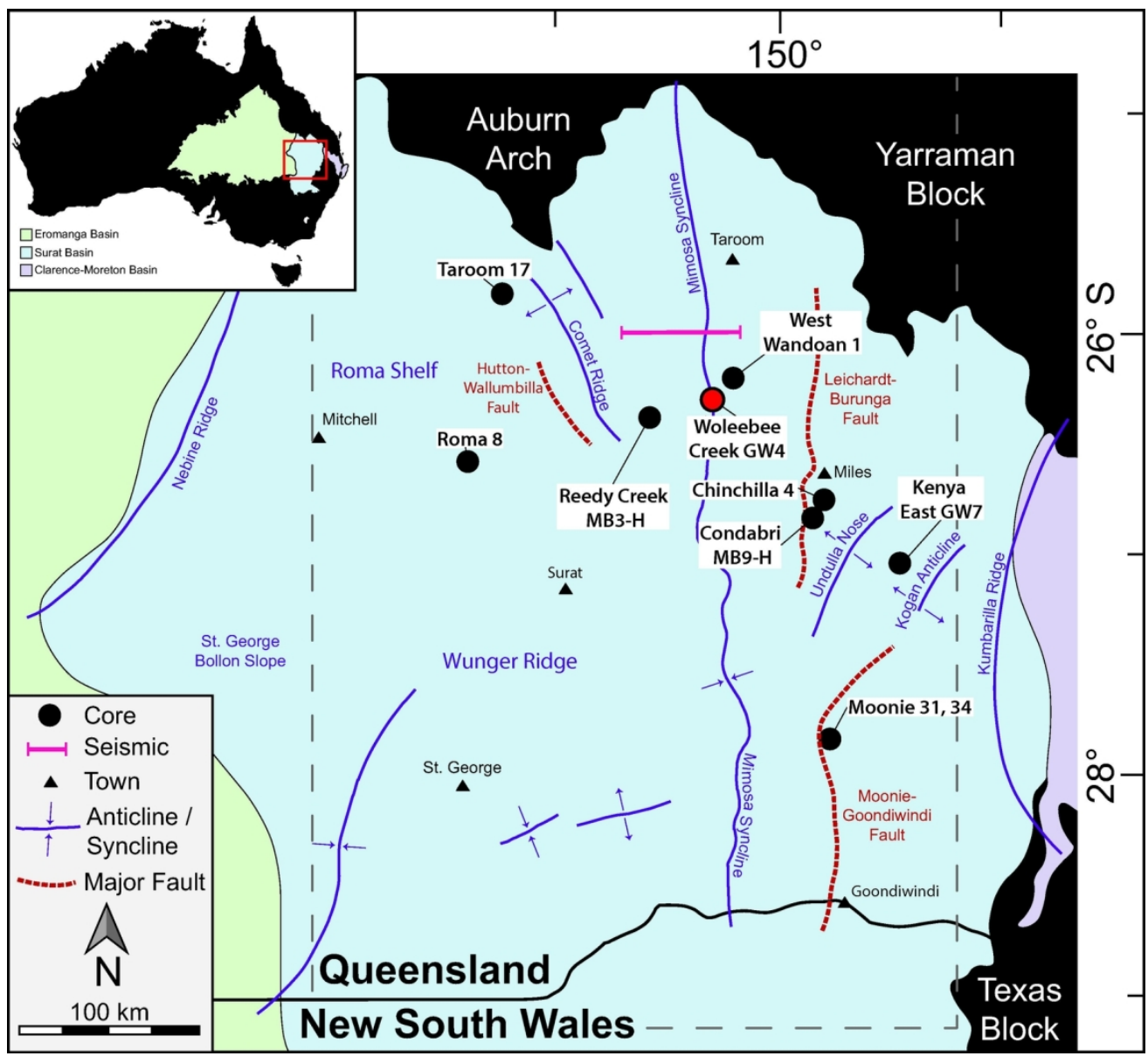

Figure 3

$140 \times 128 \mathrm{~mm}(300 \times 300$ DPI $)$ 


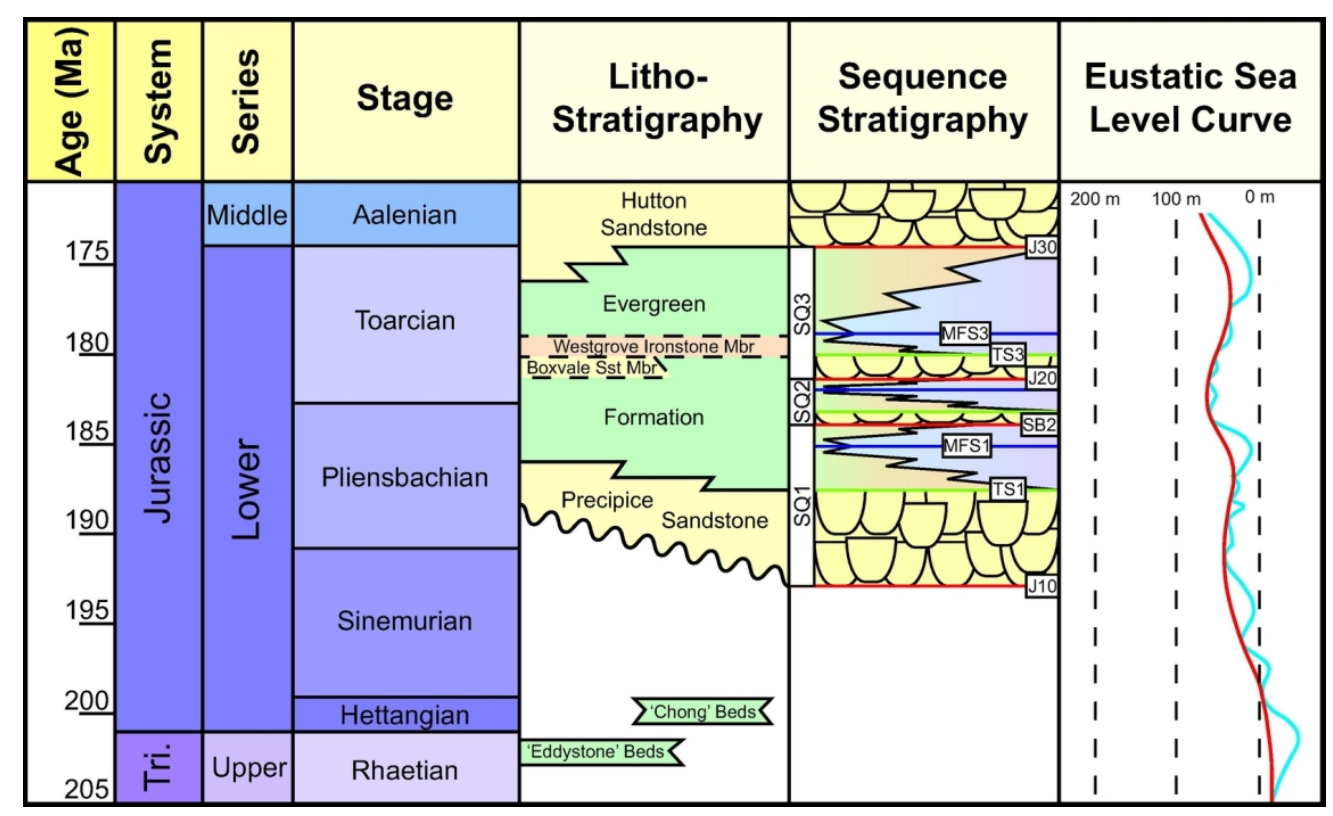

Figure 4

$140 \times 85 \mathrm{~mm}(300 \times 300$ DPI $)$ 


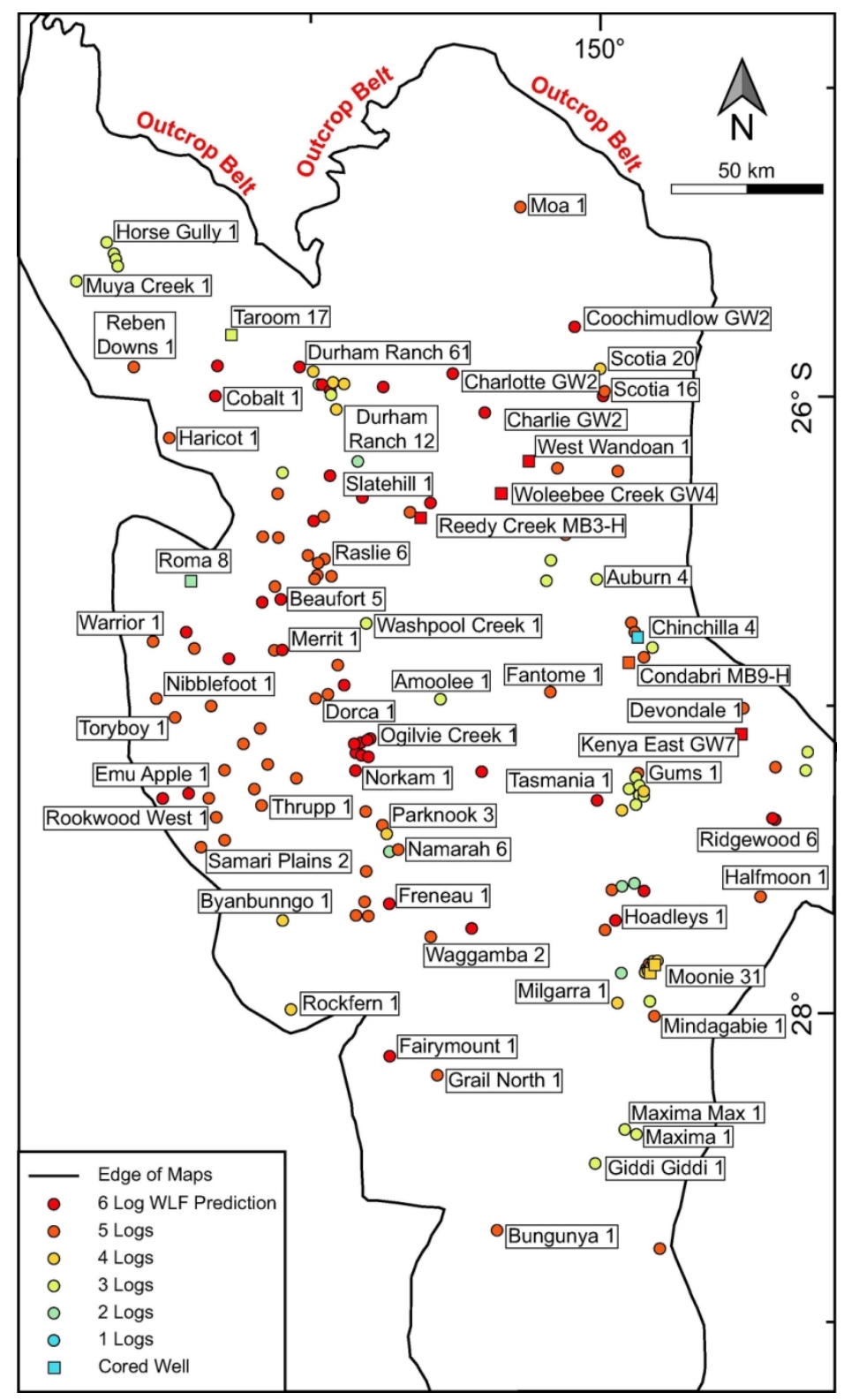

Figure 5

$90 \times 151 \mathrm{~mm}(300 \times 300 \mathrm{DPI})$ 

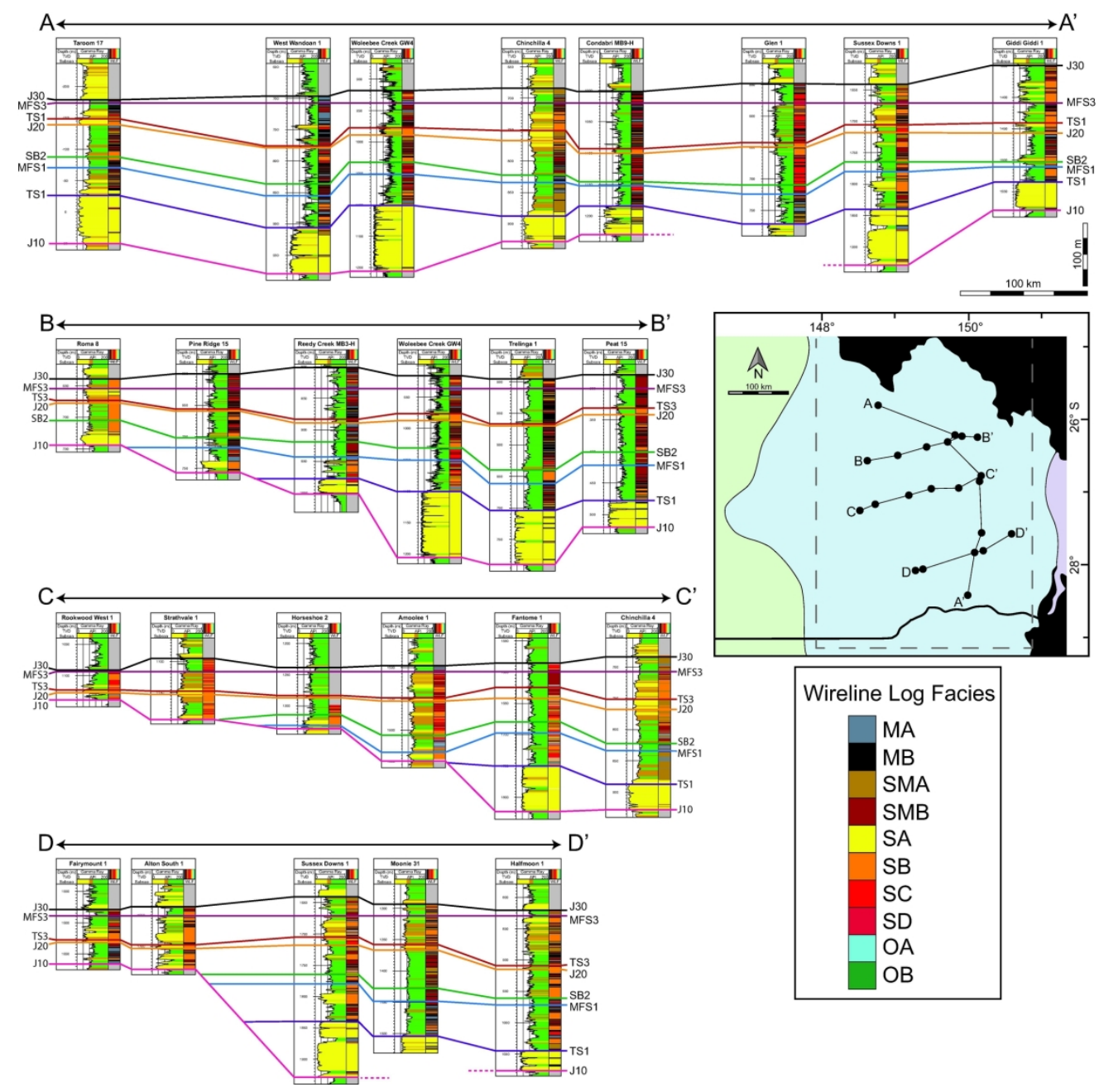

Figure 6

$197 \times 196 \mathrm{~mm}(300 \times 300$ DPI) 


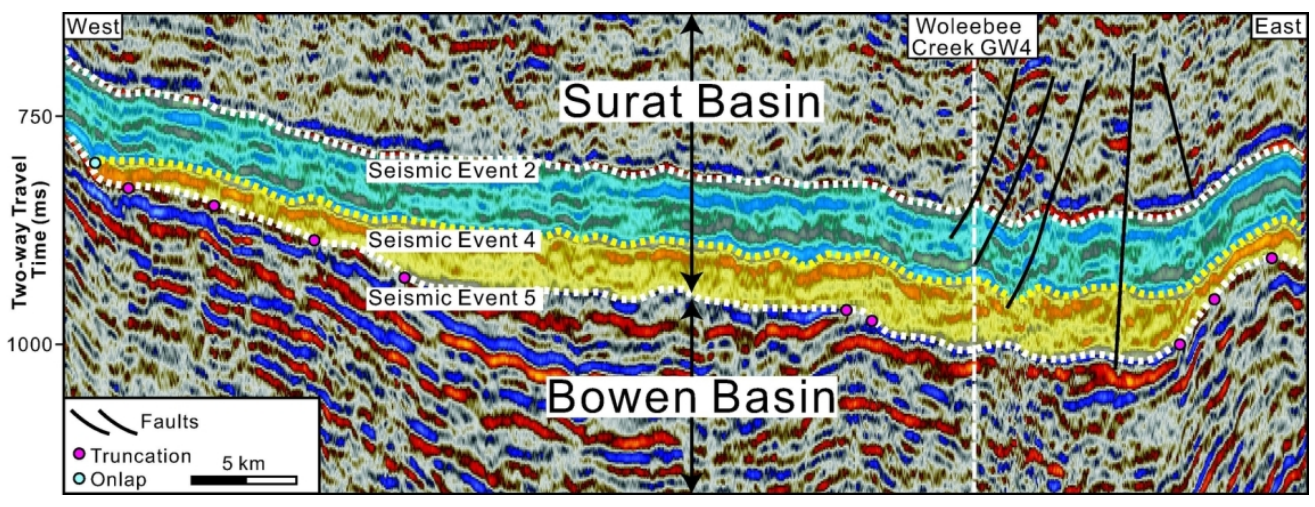

Figure 7

$140 \times 52 \mathrm{~mm}(300 \times 300$ DPI $)$ 


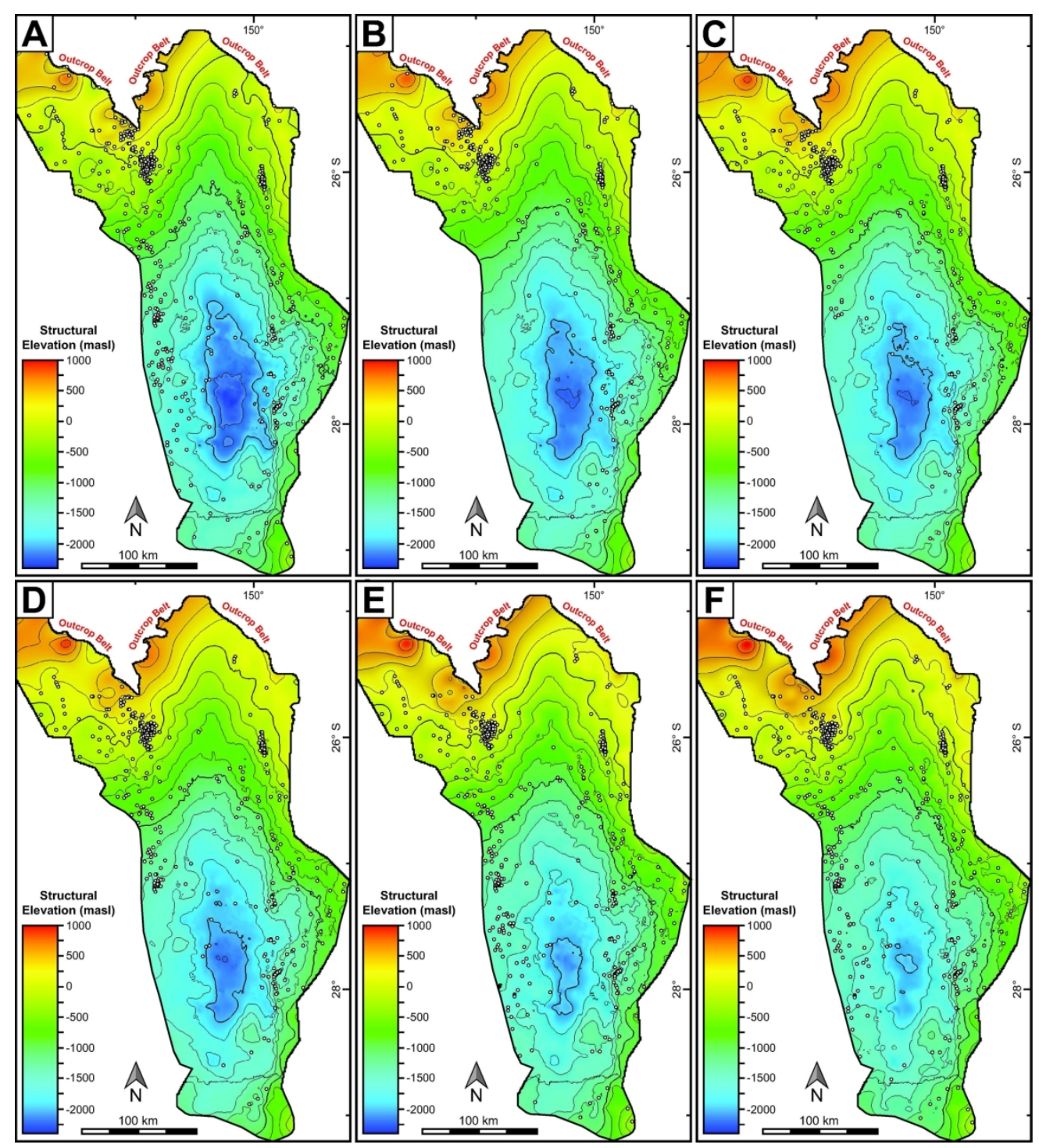

Figure 8

$167 \times 185 \mathrm{~mm}(300 \times 300 \mathrm{DPI})$ 


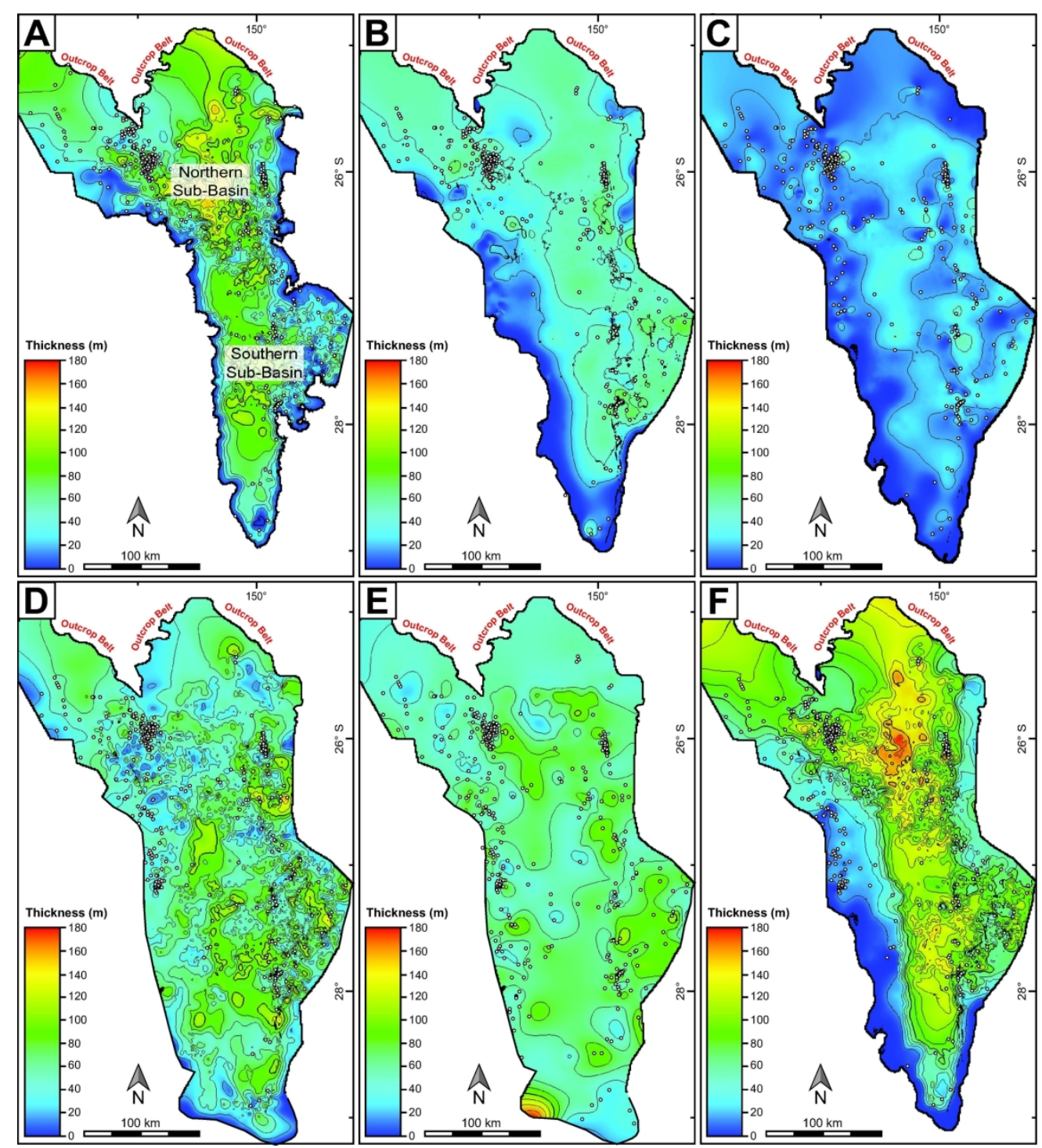

Figure 9

$167 \times 185 \mathrm{~mm}(300 \times 300$ DPI) 

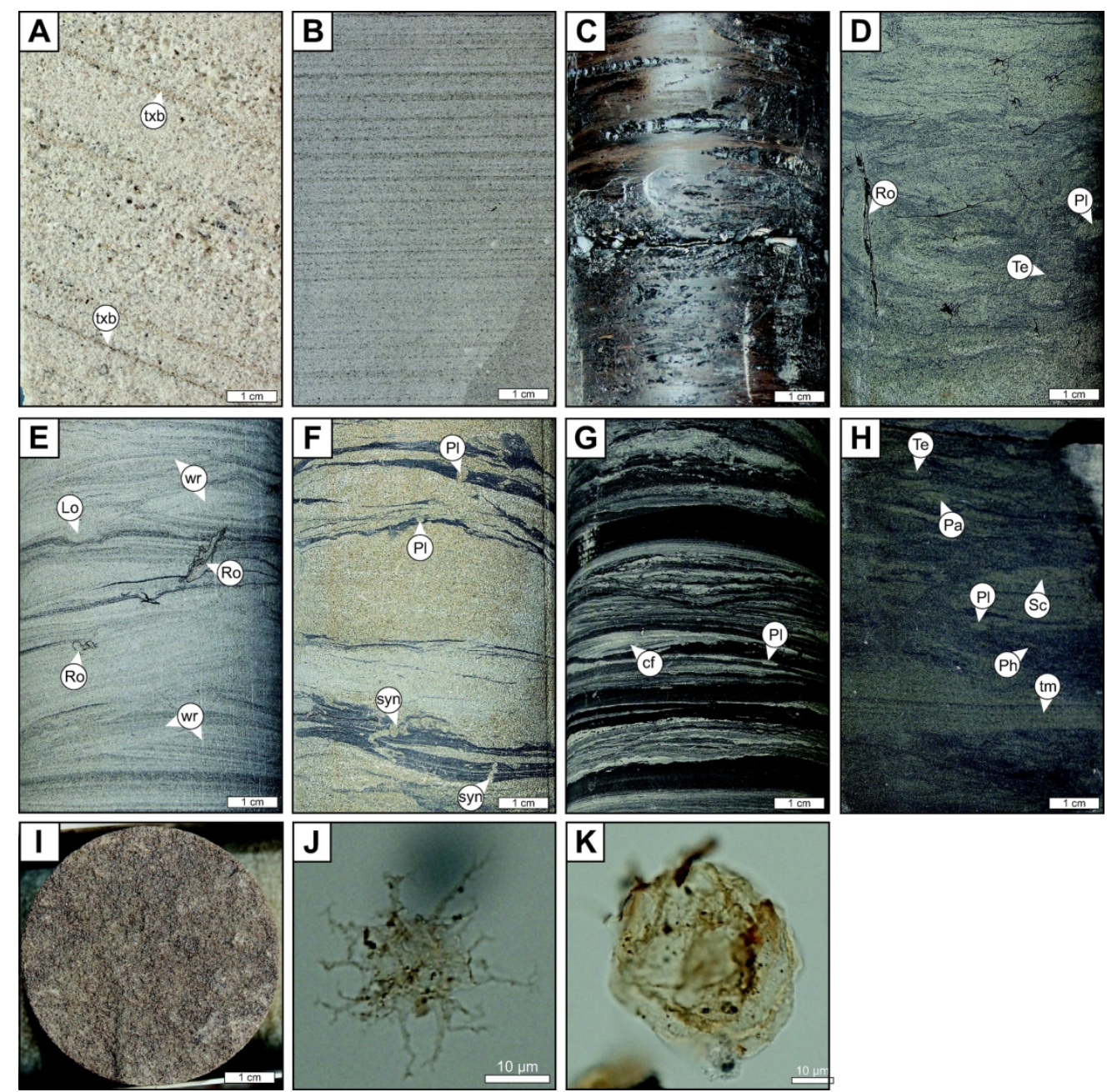

Figure 10

$180 \times 178 \mathrm{~mm}(300 \times 300$ DPI $)$ 


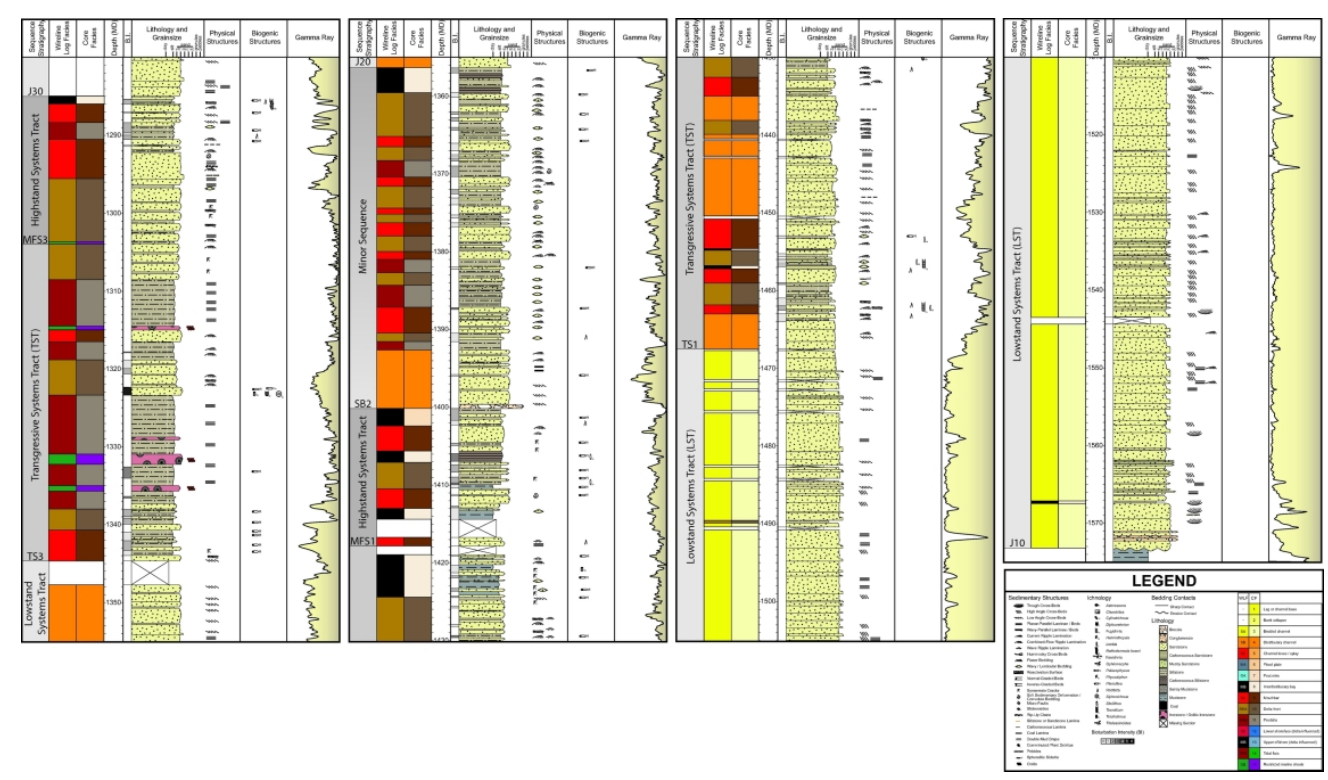

Figure 11

$286 \times 165 \mathrm{~mm}(300 \times 300$ DPI $)$ 


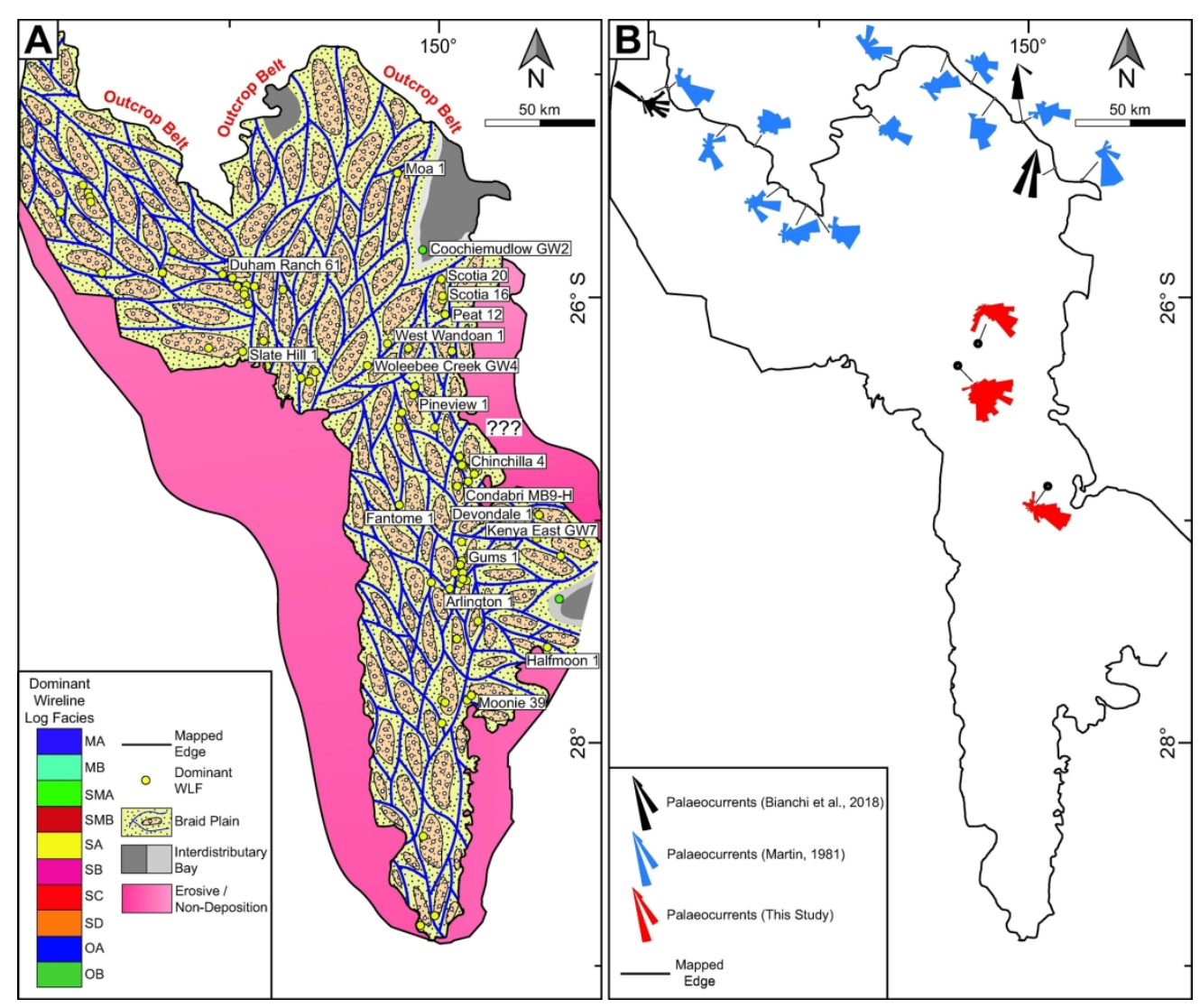

Figure 12

178x149mm ( $300 \times 300$ DPI) 


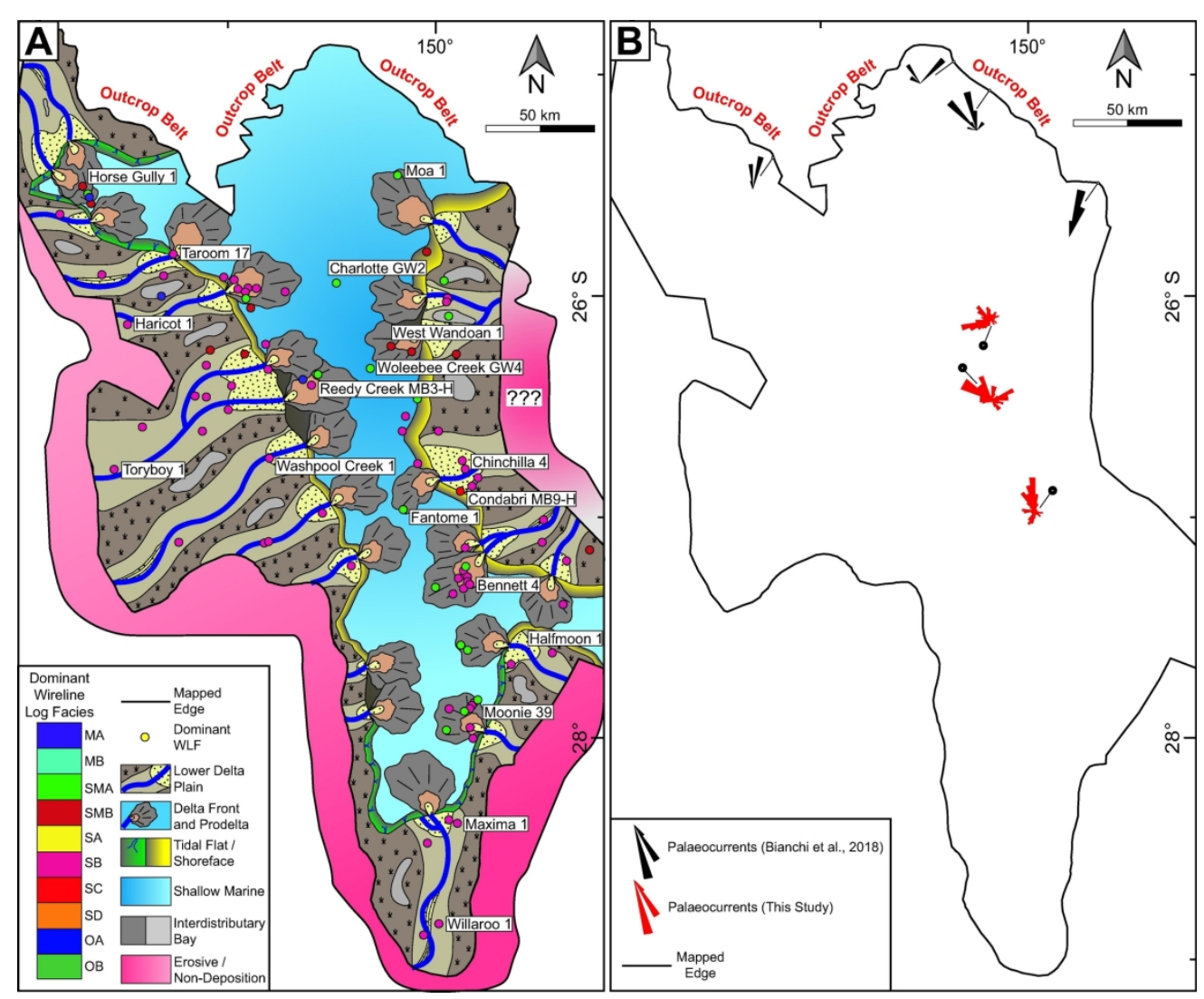

Figure 13

$181 \times 149 \mathrm{~mm}(300 \times 300$ DPI) 


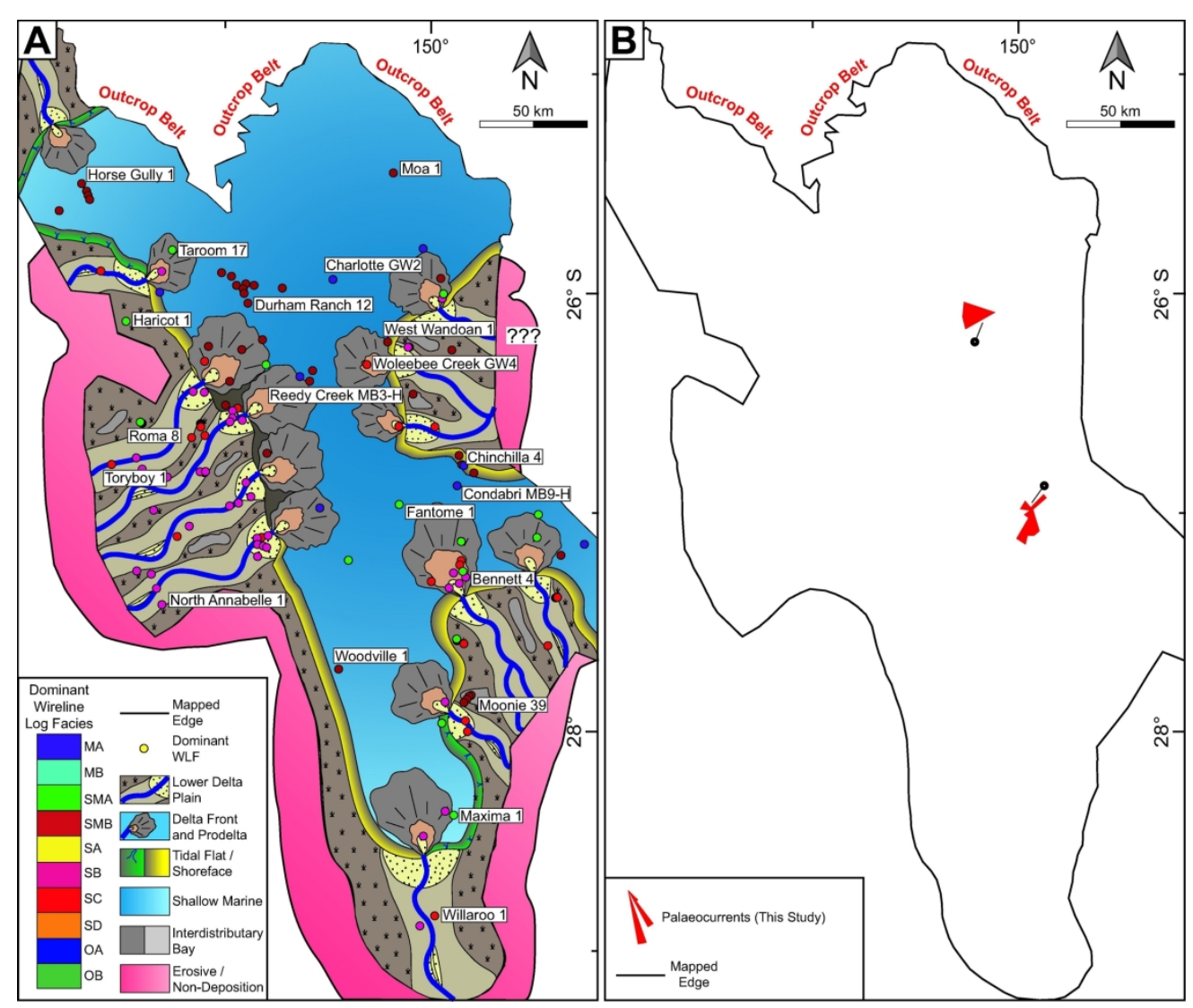

Figure 14

$181 \times 152 \mathrm{~mm}(300 \times 300$ DPI) 


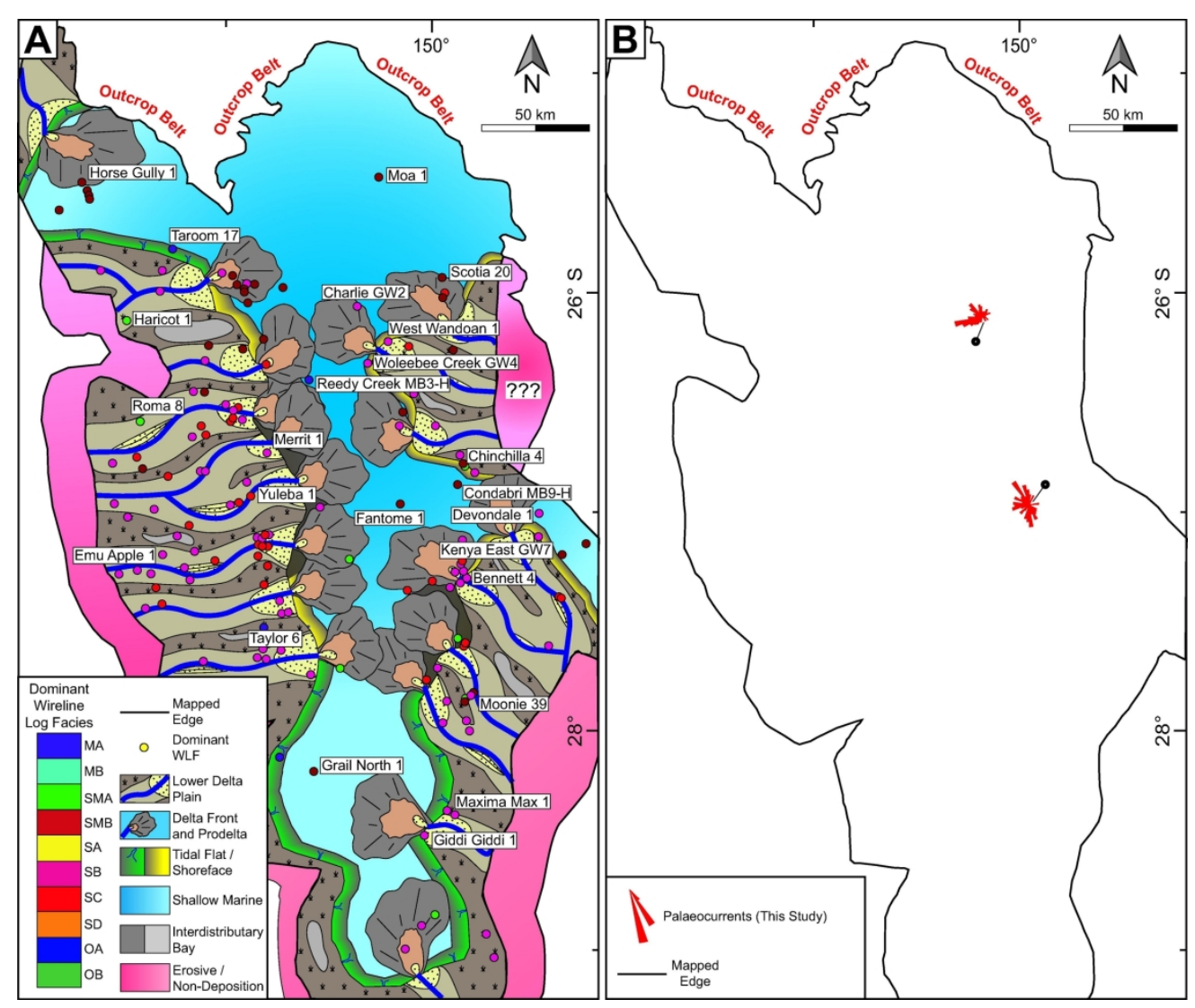

Figure 15

$181 \times 151 \mathrm{~mm}(300 \times 300$ DPI $)$ 


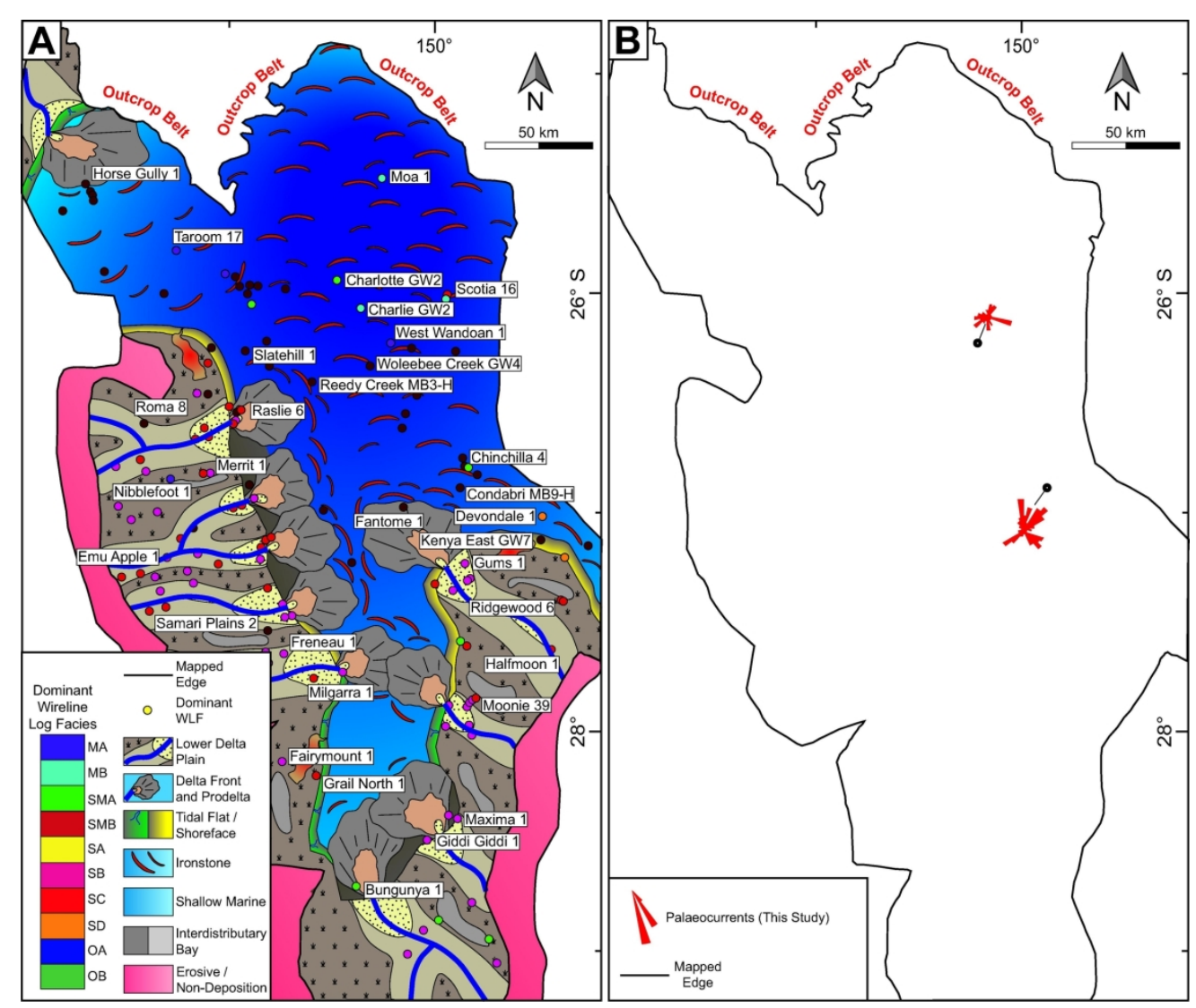

Figure 16

$181 \times 152 \mathrm{~mm}(300 \times 300$ DPI) 


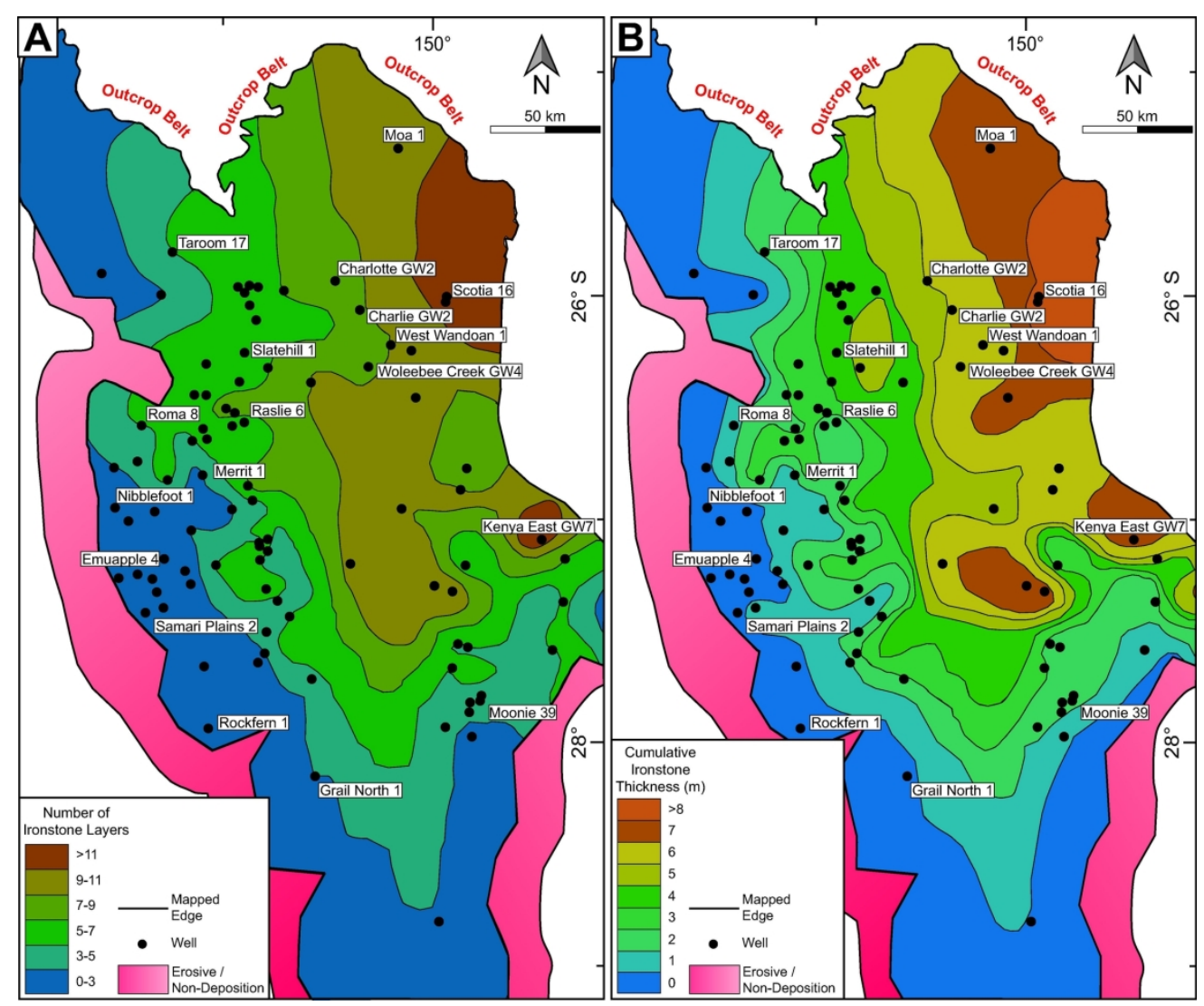

Figure 17

$179 \times 149 \mathrm{~mm}(300 \times 300 \mathrm{DPI})$ 


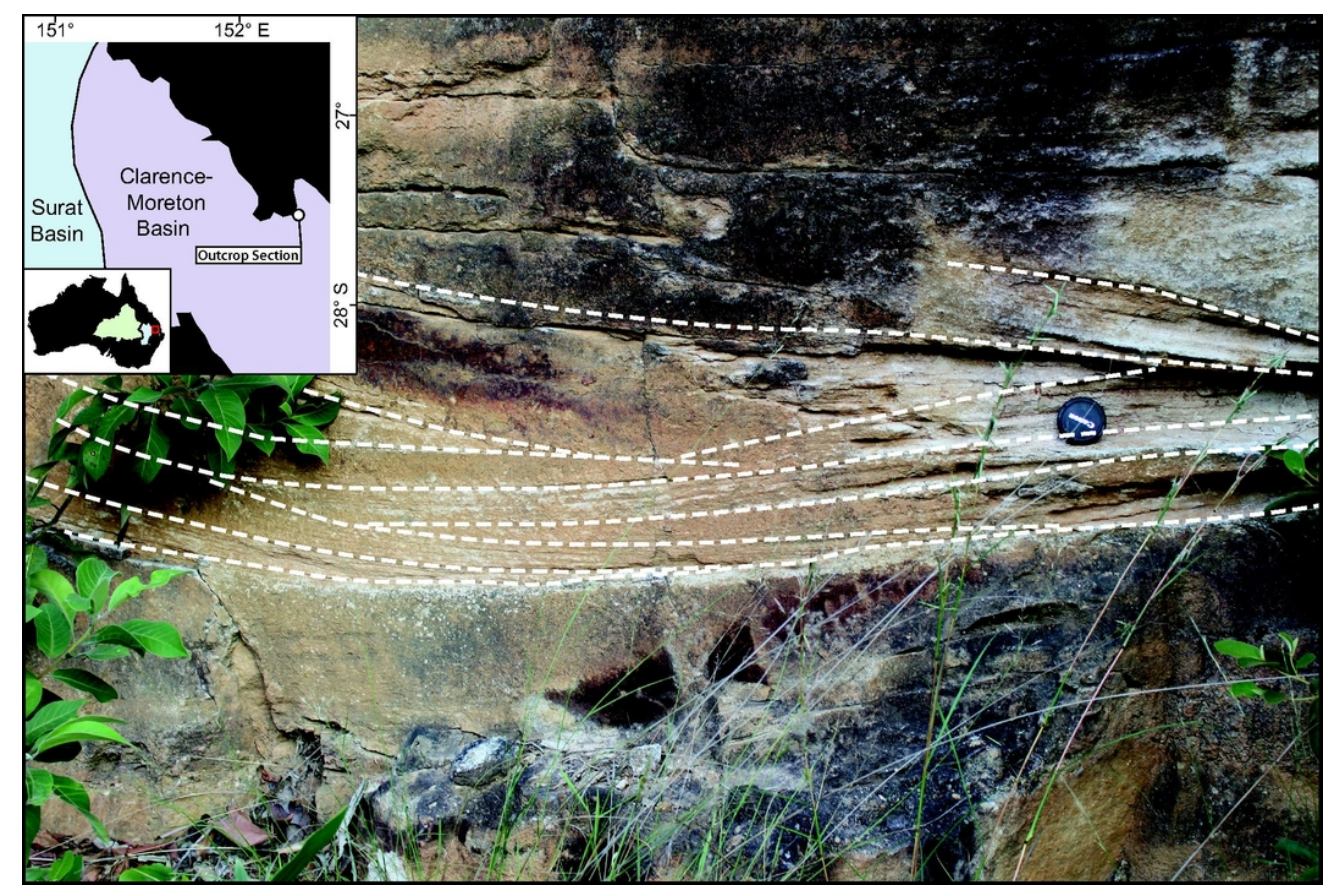

Figure 18

$90 \times 60 \mathrm{~mm}(300 \times 300 \mathrm{DPI})$ 